GARCÍA PALOMINOS, Gonzalo. "La idealización y la administrativización de la punibilidad del uso de Información Privilegiada. Un análisis de los discursos penales en la doctrina chilena".

Polít. crim. Vol. 10, № 19 (Julio 2015), Art. 5, pp. 119-158. [http://www.politicacriminal.cl/Vol_10/n_19/Vol10N19A5.pdf]

\title{
La idealización y la administrativización de la punibilidad del uso de Información Privilegiada. Un análisis de los discursos penales en la doctrina chilena.
}

\section{The idealization and administrativization of the punibility of Insider Trading. An analysis of the penal discourses in Chilean doctrine.}

\author{
Dr. Gonzalo García Palominos, L.L. M (Freiburg i.B)* \\ Académico del Departamento de Derecho Penal \\ Universidad de los Andes (Chile) \\ ggarcia@uandes.cl
}

\begin{abstract}
Resumen
El artículo analiza de manera crítica la capacidad de las propuestas teóricas, desarrolladas en nuestro país, que intentan reconstruir el injusto penal del uso de información privilegiada. La principal crítica se orienta, por una parte, en denunciar una especie de "idealización" del mercado de valores, que abarca innecesariamente a algunos submercados no organizados o informales, lo que ha obligado a reconstruir ficticiamente el injusto penal; por otra parte, se denuncia una "administrativización" del derecho penal, al constatar la renuncia al análisis del merecimiento y necesidad de la pena en la reconstrucción del injusto, aceptando, para eso, la mera disfuncionalidad generada por la vulneración normativa.
\end{abstract}

Palabras clave: Uso de información privilegiada, insider, mercado de valores, derecho penal, derecho administrativo sancionador, Ley $\mathrm{N}^{\circ} 18.045$.

\begin{abstract}
This article critically analyzes the aptitude of theories proposed by national authors attempting to reconstruct the criminal wrongness of insider trading. The main criticism is oriented, firstly, in denouncing an idealized concept of "stock market", which unnecessarily covers some unorganized or informal submarkets, forcing to reconstruct fictionally the criminal wrongfulness of insider trading. Secondly, we denounce that by abandoning the analysis of the needs and merits of criminal punishments in the reconstruction of wrongfulness, criminal law begins to look more as administrative law, accepting that the mere dysfunction generated by the violation of rules is cause enough.
\end{abstract}

Key words: Insider trade, insider, stock market, criminal law, sanctioning administrative law, Law $\mathrm{N}^{\circ} 18.045$. 
GARCÍA PALOMINOS, Gonzalo. "La idealización y la administrativización de la punibilidad del uso de Información Privilegiada. Un análisis de los discursos penales en la doctrina chilena”.

\section{Introducción.}

(aa) Los dos presupuestos metodológicos generales sobre los cuales trabaja la literatura penal mayoritaria en la reconstrucción material del desvalor de las conductas penales dañosidad social y proporcionalidad - confluyen en el llamado principio de exclusiva protección de bienes jurídicos. Dicha literatura ha sostenido, a modo general, que el derecho penal se legitima materialmente por sancionar sólo modos de conductas cuando el ejercicio de la autonomía personal traspasa y afecta la autonomía ajena (dañosidad social o principio de lesividad) $\mathrm{y}$, adicionalmente, en la medida que el valor de los intereses afectados de dicha autonomía ajena ${ }^{1}$ y el desvalor de la conducta logren justificar la intensidad de la sanción "penal": "Lo que no pueda justificar una privación de libertad y una lesión grave al honor no puede llegar a definirse como delito"2.

De estos postulados se extraen consecuencias a nivel político criminal (criminalización o descriminalización) y a nivel metodológico y dogmático (reconstrucción teleológica del injusto merecido de pena). La literatura también ha denominado estas funciones como función trascendente (crítica o política) e inmanente (dogmática) del bien jurídico ${ }^{3}$.

La función inmanente o de reconstrucción teleológica y de cualificación de la ilicitud (transformación del ilícito en injusto penal) - y aquí la importancia de esta discusión en este trabajo - es consecuencia de considerar que a diferencia de las normas de sanción introducidas en el ámbito civil, comercial o administrativo para regular u organizar ciertos ámbitos, en el derecho penal esto implica una doble intensidad en la afectación de derechos.

\footnotetext{
* Se hace justicia con mencionar que parte de la redacción de este artículo fue desarrollado antes de marzo de 2014, mientras el autor era profesor e investigador de la Facultad de Derecho de la Universidad Alberto Hurtado. Así mismo, es necesario destacar al lector que el presente trabajo es el segundo de un grupo de tres artículos referidos al delito de uso de información privilegiada y a la legitimidad de los delitos económicos. El primero de ellos fue publicado anteriormente en la misma revista en julio de 2013 con el título: "Modelo de protección en normas administrativas y penales que regulan el abuso de Información Privilegiada en la legislación chilena", y citado en cita ${ }^{\circ} 11$ del presente artículo.

${ }^{1}$ Aquí, la identificación de un "bien jurídico" constituye la búsqueda de objetos de valoración positiva que representen intereses igualmente relevantes a la libertad general (y también ambulatoria) o la conducta lesiva para dichos bienes y que permitan servir de parámetro objetivo de la desvaloración de dicha conducta.

2 Para una profundización de esta idea, véase HASSEMER, Winfried, Theorie und Soziologie des Verbrechens, Frankfurt a. M. (Alemania): Athenäum Fischer Taschenbuch Verlag, 1973; EL MISMO, "Symbolisches Strafrecht und Rechtsgutschutz", Neue Zeitschrift für Strafrecht, Heft 12. (1989), pp. 553 y ss.; MARX, Michael, Zur Definition des Begriffs „Rechtsgut“. Prolegonema einer materialen Verbrechenslehre, Bd. 65. Köln (Alemania): Carl Heymanns Verlag, 1972; SINA, Peter, Die Dogmengeschichte des strafrechtlichen Begriffs Rechtsgut, Basel (Suiza): Helbing \& Lichtenhahn, 1962, pp. 90 y ss.; ROXIN, Claus, "Es la Protección de bienes jurídicos una finalidad del derecho penal?", en: HEFENDEHL, Roland (Ed.), Teoría del Bien Jurídico, Madrid: Ed. Marcial Pons, 2007, pp. 443 y ss., p. 447; SCHÜNEMANN, Bernd, "Das Rechtsgüterschutzprinzip als Fluchtpunkt der verfassungsrechtlichen Grenzen der Straftatbestände und ihrer Interpretation", en: HEFENDEHL, Roland (Ed.), Die Rechtsgutstheorie, Baden Baden: Nomos Verlagsgesellschaft, 2003, pp. 133 y ss.; a modo de ejemplo, en la literatura chilena véase BUSTOS, Juan; HORMAZABAL, Hernán, Lecciones de Derecho Penal I, Madrid: Trotta, 1999, p. 27; GARRIDO MONTT, Mario, Derecho Penal, Parte General, Tomo I, Santiago de Chile: Editorial Jurídica de Chile, 2003, p. 30.

${ }^{3}$ Ver HASSEMER, Theorie, cit. nota ${ }^{\circ} 2$, p. 44.
} 
Polít. crim. Vol. 10, № 19 (Julio 2015), Art. 5, pp. 119-158.

[http://www.politicacriminal.cl/Vol_10/n_19/Vol10N19A5.pdf]

En un primer momento (por medio de norma de conducta reforzada por la amenaza de pena), se produce la más intensa afectación a la libertad general de decisión del ordenamiento jurídico; con posterioridad, al momento de la imposición de la pena (a través de su aplicación) se afecta o se puede afectar la libertad ambulatoria ${ }^{4}$, lesión al honor (reproche social) e, incluso, se produce una restricción importante a las posibilidades de contacto social de dichos ciudadanos ${ }^{5}$. Como consecuencia de lo anterior, la teoría de la protección de bienes jurídicos propone una exigencia adicional a la mera vulneración normativa con consecuencias metodológicas: la cualificación de la mera vulneración normativa en atención a la proporcionalidad que debe existir entre los intereses afectados por la conducta individual y protegidos a nivel extrapenal (o prepenal) y la intensidad de la intervención estatal por medio de la sanción penal ${ }^{6}$.

(bb) El proceso de reconstrucción del injusto penal según la metodología propuesta por el principio de lesividad o dañosidad social, sin embargo, no resulta ser simple de desarrollar en algunos grupos de delitos cuyo objeto de valoración positiva - representativo de la autonomía ajena - está configurado normativa o institucionalmente. Dicha dificultad no proviene solamente - como la literatura más crítica podría sostener - de una tendencia a materializar o explicar la lesividad siempre desde una perspectiva naturalista (o materialista) y causalista. Aunque sin rechazar enteramente dicha crítica, la tesis aquí propuesta es que - como se demostrará a propósito del delito de uso de información privilegiada en particular - la principal razón radica en la tendencia a generalizar o idealizar el objeto de protección. Esto, porque la metodología propuesta por la teoría de protección de bienes jurídicos exige objetos de valoración (no cosas) positivos de la realidad social concretos que se vean afectados por modos de conductas individuales, por eso desvaloradas. Con esta tendencia de la literatura y jurisprudencia a la generalización, se tiende, sin embrago, a idealizar la relación de lesividad entre la conducta desvalorada y el bien jurídico ${ }^{7}$, perjudicando no sólo el proceso de reconstrucción del injusto, sino también el desarrollo de criterios de cualificación del injusto e imputación penal. Esta tesis se demuestra, por ejemplo, en que mientras no ha existido mayor problema para explicar la naturaleza normativa de aquellas instituciones configuradas para servir individualmente y la lesividad de conductas individuales, como sucede en relación a la propiedad o el honor, no sucede lo mismo respecto a instituciones configuradas para servir a la interrelación de personas pero, respecto de las cuales, - según la moderna caracterización de Heinz Koriath

\footnotetext{
${ }^{4}$ LAGODNY, Otto, "Das materielle Strafrecht als Prüfstein der Verfassungsdogmatik", en: HEFENDEHL, Roland u. a. (Ed.), Die Rechtsgutstheorie, Baden Baden: Nomos Verlagsgesellschaft, 2003, pp. 83 - 88, p. 84 y s.

${ }^{5}$ BÖSE, Martin, “Grundrechte und Strafrecht als Zwangsrecht”, en: HEFENDEHL, Roland u. a. (Ed.), Die Rechtsgutstheorie, Baden-Baden: Nomos Verlagsgesellschaft, 2003, pp. 89 y ss., 91 y s.

${ }^{6}$ Sobre los modelos en tensión para la reconstrucción del injusto penal, véase GARCIA PALOMINOS, Gonzalo, "Del paradigma de la dañosidad social centrado en la infracción normativa al paradigma metodológico centrado en la norma de sanción: un falso dilema", en: BLANCO, R.; IRURETA, P. (Eds.) Justicia, Derecho y Sociedad, Libro en Memoria de Maximiliano Prado D., Santiago: Ediciones Universidad Alberto Hurtado, 2014, pp. 143 y ss.

7 Este fenómeno de idealización ha sido llamado equivocadamente por la doctrina alemana "desmaterialización". Véase sobre este fenómeno en los discursos penales en KRÜGER, Matthias, Die Entmaterialisierungstendenz bei Rechtsgutsbegriff, Bd. 35, Berlin: Duncker\&Humblot, 2000; sobre este fenómeno en el derecho penal económico véase GEERDS, Detlev, Wirtschaftsstrafrecht und Vermögensschutz, Lübeck: Max Schmidt-Römhild, 1990.
} 
GARCÍA PALOMINOS, Gonzalo. "La idealización y la administrativización de la punibilidad del uso de Información Privilegiada. Un análisis de los discursos penales en la doctrina chilena”.

$o$ Roland Hefendehl de la "no excluibilidad" del uso y "no rivalidad" en el consumo ${ }^{8}$ - se afirma una constitución colectiva que es difícil de lesionar individualmente, al menos en un sentido clásico.

(cc) El problema se presenta aún más complejo en los delitos del llamado derecho penal económico (en sentido estricto) ${ }^{9}$, caracterizados por su estrecha relación de accesoriedad con el derecho privado $^{10}$ - regido principalmente por sus propios fines, principios y criterios - y cuyo principal objetivo es proveer orden y estabilidad a ciertas interacciones humanas y, con ello, proteger la funcionalidad de uno o varios subsistemas económicos. La dificultad - desde el punto de vista de reconstrucción del injusto penal desde esta metodología clásica - radica en la constante tentación de homologar los fines del derecho económico y administrativo sancionador con los del derecho penal, debido a que ambos identifican su objeto de valoración positivo en la funcionalidad general de la institución. Así las cosas, como se demostrará, el derecho penal no sólo abandona su vocación subsidiaria (ultima ratio) e identifica su fines con la provisión de funcionalidad a las instituciones económicas, sino que además abandona la metodología propuesta en la reconstrucción del injusto penal. Lo anterior, se puede ver atenuado o agravado según la técnica legislativa utilizada.

Los delitos de uso y divulgación de información privilegiada que se encuentran sancionados en Chile penalmente tanto en la Ley de Mercado de Valores $\mathrm{N}^{\circ} 18.045$ de 1981 (Art. 60 e), g) y h)) (en adelante también LMV) como en el Decreto Ley $\mathrm{N}^{\circ} 3.500$ de 1980 sobre Sistema de Pensiones (Art. 159), aparentemente no son la excepción a esta problemática, según se desprende de la literatura nacional ${ }^{11}$. Como ya se ha sostenido,

\footnotetext{
${ }^{8}$ KORIATH, Heinz, "Zum Streit um den Begriff des Rechtsguts", GA, 146. Jg. Heidelberg 1999, pp. 561 583, p. 564 f.; HEFENDEHL, Roland, Kollektive Rechtsgüter im Strafrecht, Köln: Carl Heymanns Verlag KG, 2002, pp. 111 y ss.; EL MISMO, "Das Rechtsgut als materieller Angelpunkt einer Strafnorm", en: HEFENDEHL, Roland (Ed.), Die Rechtsgutstheorie, Baden Baden: Nomos Verlagsgesellschaft, 2003 , pp. $119-132$, p. 126.

9 Véase sobre el concreto amplio o restringido de derecho penal económico en: FEIJOO SÁNCHEZ, Bernardo, Cuestiones actuales de Derecho Penal, Montevideo, Buenos Aires: Ed. B de f, 2009, p. 209.

${ }^{10}$ Ver, en general, sobre la accesoriedad: ROJAS, Luis Emilio, “Accesoriedad del Derecho Penal”, en: VAN WEEZEL, Alex (Ed.), Humanizar y Renovar el Derecho Penal, estudios en memoria de Enrique Cury, Santiago: Legal Publishing/Thomson Reuters, 2013, pp. 93 -107.

${ }^{11}$ Entre la literatura más representativa se pueden nombrar ALCALDE RODRÍGUEZ, Enrique, "Uso de Información Privilegiada: Algunas consideraciones sobre el sentido y alcance de la prohibición en relación con su sujeto, objeto y sanción", Revista Chilena de Derecho, vol. 27, N 1 (2000), pp. 11 - 28; CANALES, Patricia, Información Privilegiada en el Mercado de Valores, Serie de Estudios de Anticipación/CEA, Biblioteca del Congreso Nacional de Chile, Año II, N¹8, Mayo de 2003, pp. 1 y ss.; BASCUÑ̃́N RODRIGUEZ, Antonio, "La regulación de la información Privilegiada en el mercado de Valores después de la Ley 20.382”, en: VVAA, Gobiernos Corporativos. Aspectos especiales de las Reformas a su regulación, Universidad Adolfo Ibáñez, Santiago: Editorial AbeledoPerrot, 2011, pp. 87 - 138; GARCÍA PALOMINOS, Gonzalo, "Modelo de protección en normas administrativas y penales que regulan el abuso de Información Privilegiada en la legislación chilena", Polít. Crim., Vol. 8, No 15 (Julio 2013), pp. 23 - 63. [http://www.politicacriminal.cl/Vol_08/n_15/Vol8N15A2.pdf]; GASPAR, José Antonio; ARAYA, Fernando, "Uso de Información Privilegiada: Superintendencia de Valores y Seguros, 14 de abril de 2011, Resolución Exenta N 229”, Revista Chilena de Derecho Privado, No 17 (2011), pp. 277 - 305; GUZMÁN ANRIQUE, Francisco, Información Privilegiada en el Mercado de Valores, Santiago: LexisNexis, 2007; STIPP, Anne
} 
Polít. crim. Vol. 10, № 19 (Julio 2015), Art. 5, pp. 119-158. [http://www.politicacriminal.cl/Vol_10/n_19/Vol10N19A5.pdf]

respecto de estos delitos no existe claridad en la doctrina nacional e internacional ni respecto a la configuración de lo protegido (bien jurídico) ni menos aún sobre las razones para la desvalorización de la conducta, provocando un déficit de legitimación con consecuencias prácticas (ej. reconstrucción y cualificación del injusto). Frente a dicho fenómeno, parte de la literatura sostiene una incompatibilidad entre el derecho penal y la necesidad de sanción de conductas en el mercado de valores ${ }^{12}$ - siendo especialmente crítica con la sanción del uso de información privilegiada - y consecuentemente entiende la criminalización de conductas en este ámbito como ilegítima. Mientras que otros intentan solucionar estos déficits de legitimación, reorientando la desvaloración de conductas según su lesividad para intereses individuales (concepción monista de la teoría del bien jurídico) y, con ello, aceptando la criminalización y punibilidad de algunas de estas y denunciando respecto de otras un aparente e inaceptable adelantamiento de la punibilidad ${ }^{13}$.

(dd) El problema de determinación - y de necesidad de reconstrucción racional - del injusto penal del delito de abuso de información privilegiada desde la metodología clásica (asociado íntimamente con el problema de legitimación) no es simple de comprender y se explicará recurriendo a un clásico ejemplo del derecho civil y expuesto por Cicerón en su libro "De los Deberes" (de los Oficios): Se trata de un caso en que un sujeto honesto lleva

Caroline, El Delito de Abuso de Información Privilegiada, Bogotá, Colombia: Editorial Leyer, 2009 (en su último capítulo se refiere al derecho chileno); ONFRAY VIVANCO, Arturo, "Ilícitos contra la información en las transacciones de valores", Revista de Derecho Consejo de Defensa del Estado, 우 5 (2001), pp. 73 105; PFEFFER U., Francisco, "Concepto de información privilegiada y deberes de conducta de quienes están en posesión de ella, a la luz de la jurisprudencia emanada de la Excma. Corte Suprema", Revista de Derecho Comercial, Universidad de Chile, $\mathrm{N}^{\circ} 1$ (2010), pp. 155-181; EL MISMO, "Nuevos deberes informativos y precisiones en torno al concepto de información privilegiada en el contexto de la ley que perfecciona el gobierno corporativo en empresas privadas.", Revista Actualidad Jurídica, Universidad del Desarrollo, № 22 (2010), pp. 181-203; EL MISMO, "Información Privilegiada. Nuevos criterios asentados en sentencias de la Excma. Corte Suprema.", Revista Derecho Público Iberoamericano, Universidad del Desarrollo No 5 (2014), pp. 289-297; PIÑA ROCHEFORT, Juan Ignacio, "Algunos problemas del delito de uso de información privilegiada", Cuadernos de Extensión Jurídica, Santiago, tomo 19 (2009), pp. 113 - 135; PRADO PUGA, Arturo, "Acerca del concepto de Información Privilegiada en el mercado de valores chileno: Su alcance, contenido y Límites", Revista Chilena de Derecho, vol. $30 \mathrm{~N}^{\circ} 2$ (2003), pp. 237 - 269; RIED UNDURRAGA, José Miguel, "Fundamentos de la Prohibición del Uso de la Información Privilegiada en Chile: Una visión crítica", Revista Chilena de Derecho, vol. 31, ํ 3 (2004), pp. 439 - 463; RIED UNDURRAGA, José Miguel, "El caso Consorcio 2 - Banco de Chile: Información Privilegiada y Potestad sancionadora de la Administración, en: VVAA, "Sentencias Destacadas 2005 una mirada desde la perspectiva de las políticas públicas", Revista del Instituto Libertad y Desarrollo, Santiago, 2005, pp. 31 - 44; ROSAS, Juan Ignacio, "El Delito de Abuso de Información Privilegiada en el Mercado de Valores: Análisis crítico de la regulación contenida en la Ley No 18.045", Revista Gaceta Jurídica, № 299 (2005), pp. 7 - 24; SALAH ABUSLEME, María Agnes, Responsabilidad por uso de Información Privilegiada en el Mercado de Valores, Santiago: LexisNexis, 2004; VASQUEZ PALMA, María Fernanda, "Revisión del ámbito de aplicación subjetivo y objetivo de la noción de uso de información privilegiada en Chile: un examen de la normativa a la luz de las tendencias doctrinales y jurisprudenciales", Revista de Derecho Universidad Católica del Norte, Año 17 - No 2 (2010), pp. 239-297. MONTENEGRO, Alex (Tesis de grado), Tutela penal de la Información privilegiada en la Ley 18.045 sobre mercado de valores, Memoria para optar al grado de Licenciado en ciencias jurídicas y sociales, Pontificia Universidad Católica de Chile, Valparaíso, Chile, 2004.

${ }_{12}$ Véase LARS, Hild, Grenzen einer strafrechtlichen Regulierung des Kapitalmarktes, Frankfurt a. M (Alemania): Peter Lang Verlag, 2004, p. 189; PARK, Tido, "Kapitalmarktstrafrecht und Anlegerschutz", NStZ, Heft 7, 2007, p. 369; pp. 376 y ss.

${ }^{13}$ Véase LARS, Grenzen, cit. nota ${ }^{\circ} 12$, pp. 17 y ss; ZIOUVAS, Dimitris, Das neue Kapitalmarktstrafrecht Europäisierung und Legitimation, Köln: Editorial Carl Heymanns, 2005. pp. 260 y ss. 
GARCÍA PALOMINOS, Gonzalo. "La idealización y la administrativización de la punibilidad del uso de Información Privilegiada. Un análisis de los discursos penales en la doctrina chilena”.

víveres en su barco desde Alejandría a Rodas, en un contexto de escasez y hambre en esta última. El sujeto posee la información, por él obtenida gracias a su observación, de que junto a él han partido otras naves con trigo en dirección al mismo puerto de Rodas. La interrogante que se hace Cicerón es la siguiente: ¿debía el sujeto honrado informar de las condiciones del mercado a sus contrapartes o puede callarse y vender su trigo al mejor precio posible?; ¿estará obligado él a decir a los rodios todo aquello que a ellos les podría interesar ${ }^{14}$ ? Nosotros podemos agregar a dicha interrogante, pero esta vez en sentido negativo, la siguiente: ¿estaba prohibido a dicho hombre honesto aprovecharse de sus ventajas informativas? Para Cicerón, en la respuesta de Diógenes ("pues es la naturaleza lo que une a todos los hombres en la sociedad") y ante la posible justificación del deber de informar, señala: "¿por ventura, es el espíritu de esta sociedad que el hombre nada tenga suyo propio? Si esto es así, aun es injusticia el que se venda cosa alguna, sino darlo todo" ${ }^{\text {. }}$ En otras palabras, y como señala Enrique Barros en un análisis al mismo caso para el derecho civil, la negociación contractual parte del supuesto que cada parte cautela su propio interés $\mathrm{y}$, por lo mismo, la existencia de especiales deberes positivos de informar o negativos de abstenerse de utilizar la ventaja informativa en beneficio propio son excepcionales y provienen principalmente de deberes legales o de la buena fe contractual ${ }^{16}$. Tanto Urs Kindhäuser en Alemania - haciendo un símil al mercado de automóviles usados - como Stuart Green en Estados Unidos - haciendo lo propio en la compra de un cuadro en un mercadillo ${ }^{17}$ - se formulan la misma pregunta: ¿por qué si, en general, no existe un deber de no beneficiarse de las ventajas informativas para un negocio común, en cambio, en el mercado de valores se entiende como un injusto (administrativo y penal) usar una información no conocida por las contrapartes? ¿Qué fundamenta este deber? Pero aún más importante: Existiendo efectivamente estos deberes ¿qué legitima la intervención del derecho penal en dicho ámbito?

Como ya se ha sostenido, en la literatura chilena sobre el delito de abuso (uso y divulgación) de información privilegiada no es posible encontrar una opinión única sobre las razones de la desvaloración y, con ello, de los modelos de protección que sirven de fundamento a las normas de conducta y de sanción, produciéndose una constante tensión en la interpretación de las normas jurídicas. En trabajos anteriores ${ }^{18}$, sin embargo, hemos demostrado tanto desde una perspectiva histórica como sistemático-normativa que la regulación chilena ha sufrido un cambio paulatino desde un modelo de protección individual (fiduciary duty theory, misappropriation theory y el modelo de protección patrimonial) a uno institucional (colectivo). Con ello, se ha optado por rechazar el fundamento de los deberes positivos y/o negativos relativos a la información relevante

\footnotetext{
${ }^{14}$ Véase CICERÓN, Tulio, Obras Completas, T. IV, Capítulo 3 de los Oficios, Libro XII, (Traducción de Valbuena, Manuel), pp. 173 y ss. (http://www.bibliojuridica.org/libros/libro.htm?l=774)

${ }^{15}$ Véase CICERÓN, (Capítulo 3, Libro XII), cit. nota n ${ }^{\circ}$ 14, p. 174.

${ }^{16}$ BARROS, Enrique, Tratado de Responsabilidad Extracontractual, Santiago: Ed. Jurídica de Chile, 2006, pp. 1017 y ss. (Hago justicia en reconocer que conocí de este ejemplo del derecho civil, luego que el prof. Dr. Jorge Larroucau, en ese entonces académico de la Universidad Alberto Hurtado, me recomendara la lectura del Manual antes citado).

${ }^{17}$ GREEN, Stuart, Mentir, hacer trampas y apropiarse de lo ajeno, Madrid, Barcelona, Buenos Aires: Marcial Pons, 2013, p. 312 y s.

${ }^{18}$ GARCÍA PALOMINOS, “Modelo de protección”, cit. nota nº 11, pp. 23 - 63.
} 
Polít. crim. Vol. 10, № 19 (Julio 2015), Art. 5, pp. 119-158.

[http://www.politicacriminal.cl/Vol_10/n_19/Vol10N19A5.pdf]

desde la idea de fraude o engaño por vulneración de deberes fiduciarios en relación tanto a los accionistas como al emisor o al mercado. También se ha rechazado que la fundamentación esté radicada en un deber negativo de no lesionar el patrimonio de la contraparte anónima en la transacción, principalmente por la inexistencia de una relación de causalidad entre el uso de información privilegiada y la decisión de compra o venta de valores por parte del inversor ${ }^{19}$. Así las cosas, las normas de conducta y de sanción, como las que son objeto del presente análisis, sólo cumplirían en este modelo institucional la función de proteger la capacidad de funcionamiento de dichos mercados y con ello el deber provendría de una necesidad institucional.

Con esto, se producen varios problemas de relevancia político criminal y dogmática que deben ser solucionados por los discursos y propuestas dogmáticas. Estos problemas dicen relación con los efectos que se producen en la reconstrucción del injusto penal cuando paralelamente se identifica la finalidad de protección penal con la funcionalidad institucional, primariamente función del derecho económico y administrativo. En concreto, el problema dice relación con la dificultad de reconstruir el desvalor de la conducta y las condiciones que deben reunirse para una razonable aplicación de la norma de sanción penal: “¿cuándo aparece como justo y razonable reaccionar con la pena?”20.

El objetivo general del presente artículo es, entonces, llevar a cabo un análisis preliminar y crítico de los discursos dogmáticos vinculados a la lesividad de los delitos de uso y difusión de información privilegiada establecidos en la LMV como técnica de reconstrucción del injusto y legitimador de la intervención estatal. En especial, se espera definir las razones que dificultan la reconstrucción de un injusto cualificado desde esta metodología. La tesis que se intentará acreditar señala que, si bien los discursos penales han tomado como punto de partida de la reconstrucción del analizado injusto penal la metodología propuesta por la teoría de protección bienes jurídicos, no obstante aquello, no han sido capaces no sólo de reconstruir mínimamente la lógica lesiva, sino que además de responder a la necesidad de cualificación del injusto penal. Las razones, ya se encuentran expuestas en el título de este trabajo: la Idealización de la lesividad social y la administrativización de la punibilidad del uso de Información Privilegiada.

\section{Estado actual de los discursos dogmáticos en la literatura chilena sobre la lesividad del uso de información privilegiada.}

La doctrina penal chilena relativa al delito de uso y divulgación de información privilegiada, se ha desarrollado sólo en los últimos 15 años, siendo coincidente con la última fase de modernización del mercado de valores ${ }^{21}$. Probablemente el mayor problema

\footnotetext{
${ }^{19}$ Véase al respecto GARCÍA PALOMINOS, "Modelo de protección”, cit. nota n 11, p. 31.

${ }^{20}$ En términos generales sobre la legitimación de la legislación penal FRISCH, Wolfgang, "Geglückte und folgenlose Strafrechtsdogmatik", en: ESER, Albin; HASSEMER, Winfried; BURKHARDT, Björnd, Die deutsche Strafrechtswissenschaft vor der Jahrtausendwende, München: H. Beck, 2000, pp. 159 y ss; EL MISMO, "Rechtsgut, Recht, Deliktsstruktur und Zurechnung im Rahmen der Legitimation staatlichen Strafens", en: HEFENDEHL, Roland (Ed.), Die Rechtsgutstheorie, Baden Baden: Nomos Verlagsgesellschaft, 2003, pp. 215 y ss.

${ }^{21}$ Sobre las distintas fases de desarrollo ver GARCÍA PALOMINOS, "Modelo de protección", cit. nota ${ }^{\circ}$ 11 , pp. 40 y ss.
} 
GARCÍA PALOMINOS, Gonzalo. "La idealización y la administrativización de la punibilidad del uso de Información Privilegiada. Un análisis de los discursos penales en la doctrina chilena”.

que ha enfrentado ha sido, precisamente, su incapacidad para identificar la diversidad de modelos de desvaloración de conductas (o de protección) y, con ello, las consecuencias de la adopción de cada uno de ellos. Por su parte, la reconstrucción valorativa del injusto penal de estos delitos propuesta durante esta fase discurre entre (1.) un acuerdo no absoluto, pero mayoritario, en relación al modelo de protección y (2.) una tensión metodológica relativa a los deberes que la fundamentan. Ambas tensiones deben ser aquí aclaradas.

\subsection{Tensiones del modelo institucional.}

El modelo institucional defiende una tesis dualista del bien jurídico que, a su vez, intenta explicar de manera conjunta el ámbito de valoración positivo que permite reconstruir la desvalorización (o valoración negativa) tanto del uso (art. 60 letras e) y g)) como de la divulgación (art. 60 letras i)) de información privilegiada. Estas tesis institucionales propuestas en la literatura chilena discurren sobre un mismo eje: la funcionalidad del "mercado de valores". Unas y otras se diferencian sólo en la acentuación de sus diversos aspectos representativos. Mientras para unas el aspecto funcional o funcionamiento general del mercado debe ser puesto en relieve, otras acentúan alguna condición o presupuesto concreto esencial para dicha funcionalidad del sistema, como la confianza en el mercado de valores o la igualdad, el igual acceso a la información, la transparencia del mercado, etc.

Así, por ejemplo, la identificación del bien jurídico protegido directamente en la condición de "Igualdad", proviene de un argumento del propio legislador nacional. Ya en la exposición de motivos de la incorporación de la Ley $\mathrm{N}^{\circ} 18.045$, en su versión original de 1981, como en las posteriores modificaciones en la Leyes $\mathrm{N}^{\circ} 19.301$ de 1994, así como durante la introducción de tipos penales en dicha ley y su ampliación en la Ley $\mathrm{N}^{\circ} 19.705$ de 2000 y N$^{\circ} 20.382$ de 2009 es posible encontrar argumentos coincidentes relativos a la protección de la igualdad y equidad entre los participantes en el mercado de valores. Dicha "igualdad" no es, sin embargo, entendida uniformemente. Algunas veces se plantea como objeto de valoración positiva preexistente que se vería afectado negativamente por el uso o divulgación de información privilegiada y otras como condición necesaria de proveer institucionalmente. Lo anterior no es necesariamente errado, principalmente si se entiende que en estas propuestas y discusiones se plantean fundamentaciones no sólo de carácter penal. Así, por ejemplo, en palabras del legislador en la época de discusión de la Ley 19. 301 de 1994, el mercado debe proveer igualdad de condiciones de acceso a la información, de manera tal que ninguna de las partes, al negociar, tenga más información que la otra: problema de asimetría en la información ${ }^{22}$. Por su parte, la Superintendencia de Valores y Seguros (en adelante SVS) ha señalado que "El bien jurídico protegido por las normas sobre información Privilegiada es la mayor igualdad posible en que deben encontrarse los que negocien en el mercado de valores" 23 y con ello relaciona la protección con una especie de colaboración u "objetivo a lograr" y su correlativo "derecho a la igualdad". La Corte

\footnotetext{
${ }^{22}$ Intervención Superintendente de Valores y Seguros, en: Actas de Formación de la Ley 19.301 de 1994, Sesión del Senado 15 octubre de 1993, Legislatura 327ª, Extraordinaria, pp. 25 y s; Actas de Formación de la Ley 19.301 de 1994, Primer Informe Comisión de Hacienda, 15 Octubre de 1993, pp. 30 y ss.

${ }^{23}$ Ver en Superintendencia de Valores y Seguros, Dictámenes del Mercado de Valores 1981 - 1999, en: Revista de Valores, Informe Interno de la Fiscalía de Valores, 1998, p. 58.
} 
Polít. crim. Vol. 10, № 19 (Julio 2015), Art. 5, pp. 119-158.

[http://www.politicacriminal.cl/Vol_10/n_19/Vol10N19A5.pdf]

Suprema, por el contrario, ha señalado que “(...) lo que se protege con nuestra normativa legal no es el derecho a la información, sino el derecho de los distintos operadores a intervenir en el mercado teniendo acceso igualitario a la información (...)"24. Esta igualdad es concebida, sin embargo, como requisito o condición para la configuración de un mercado "equitativo, competitivo, ordenado y transparente" 25 . No se trata, por tanto, de una igualdad informativa general o protección de un estado de igualdad ya garantizado por la institución y sus sistemas, sino de un derecho al igual acceso a la información. Esta opinión, aun cuando es capaz de contestar correctamente a las críticas formuladas por la literatura, especialmente proveniente del derecho económico ${ }^{26}$, no da respuesta a si se trata de un derecho general a la igualdad de acceso a toda la información o se trata de la igualdad de acceso a la información garantizada en ciertos mecanismos o sistemas formales del mercado de valores chileno o se basa en el mero cumplimiento de deberes extrapenales. Dicha falta de determinación, en concreto, si bien no genera graves problemas en el ámbito del derecho económico y administrativo, atenta contra la reconstrucción de los tipos penales en análisis, lo que se demostrará más abajo.

La literatura chilena mayoritaria, sin embargo, ha optado por entender que el bien jurídico protegido en los delitos de uso de información privilegiada es la fe pública o la confianza en el mercado de valores o en la igualdad de acceso a la información relevante, conceptos que se toman como sinónimos ${ }^{27}$. Esta tendencia encuentra su sustento en los fundamentos provistos por el propio legislador, en el sentido que, por medio de la prohibición del uso de información privilegiada y su sanción, se busca, por un lado, evitar la discriminación en el conocimiento de la información y cumplir así el objetivo de una participación igualitaria de oportunidad en la información, y por otro, dar una mayor confianza al inversionista en general en la institución del mercado de valores. En relación a este último punto, se destaca que sería la principal característica de los mercados de valores la búsqueda constante de la protección de la fe o confianza pública ${ }^{28}$. Como se puede observar, la argumentación en

\footnotetext{
${ }^{24}$ Ver Sentencia Exc. Corte Suprema, causa Rol Nr. 3.364 de 2006, considerando Nr. 14; véase el análisis de GUZMÁN ANRIQUE, Información Privilegiada, cit. nota ${ }^{\circ}$ 11, p. 78.

${ }^{25}$ Véase en: Superintendencia de Valores y Seguros, Dictámenes del Mercado de Valores 1981 - 1999, en: Revista de Valores, Informe Interno de la Fiscalía de Valores, 1998, p. 560.

${ }^{26}$ Esta posición es especialmente intensa en la literatura norteamericana; en la literatura chilena ver RIED UNDURRAGA, "Fundamentos de la Prohibición”, cit. nota n 11, pp. 447 y ss.

${ }^{27}$ Destacan en esta posición: PRADO PUGA, “Acerca del concepto de Información Privilegiada", cit. nota ${ }^{\circ}$ 11, pp. 262 y ss.; SALAH, Responsabilidad por uso de Información Privilegiada, cit. nota n 11, pp. 215 y ss.; ROSAS, "El Delito de Abuso", cit. nota $\mathrm{n}^{\circ}$ 11, pp. 10 y ss.; MONTENEGRO, Tutela penal de la Información privilegiada, cit. nota $\mathrm{n}^{\circ} 11$, pp. 41 y ss.; en parte y algo difuso ONFRAY, "Ilícitos contra la información", cit. nota $\mathrm{n}^{\circ} 11$, pp. 73 y ss.; contrario y críticos a esta, ver: RIED UNDURRAGA, "Fundamentos de la Prohibición”, cit. nota ${ }^{\circ}$ 11, pp. 449 y ss.; GUZMÁN ANRIQUE, Información Privilegiada, cit. nota $\mathrm{n}^{\circ} 11$, pp. 107 y ss.

${ }^{28}$ Intervención Superintendente de Valores y Seguros, en: Actas de Formación de la Ley 19.301 de 1994 , Sesión del Senado 15 octubre de 1993, Legislatura 327 a , Extraordinaria, pp. 98 y ss.; sobre los objetivos del legislador ver: Protección a los accionistas minoritarios frente a la toma de control de una sociedad anónima abierta, en: Revista Chilena de Derecho, Vol. 22, N 3 (1995), pp. 417 y ss.; RIED UNDURRAGA, "Fundamentos de la Prohibición", cit. nota $\mathrm{n}^{\circ}$ 11, pp. 449 y ss.; CANALES, cit. nota $\mathrm{n}^{\circ} 11$, pp. 10 y ss.; MONTENEGRO, Tutela penal de la Información privilegiada, cit. nota $\mathrm{n}^{\circ} 11$, pp. 41 y ss.; en parte y algo difuso ONFRAY, "Ilícitos contra la información", cit. nota $\mathrm{n}^{\circ} 11$, pp. 73 y ss.; contrarios y críticos a esta, ver: RIED UNDURRAGA, "Fundamentos de la Prohibición”, cit. nota n 11, pp. 449 y ss.; GUZMÁN ANRIQUE, Información Privilegiada, cit. nota n ${ }^{\circ}$ 11, pp. 107 y ss.
} 
GARCÍA PALOMINOS, Gonzalo. "La idealización y la administrativización de la punibilidad del uso de Información Privilegiada. Un análisis de los discursos penales en la doctrina chilena”.

torno a la "confianza en el mercado de valores" como bien jurídico, desarrollada por parte de la literatura chilena, estaría compuesta por la relación de tres elementos: La confianza, el objeto de la confianza y la capacidad de funcionamiento del mercado o funcionamiento adecuado.

Según la literatura chilena y los fundamentos del legislador, la protección de la confianza o fe pública sería consecuencia de entenderla como principal condición para el adecuado funcionamiento del mercado de valores. Como lo señalaba el Ministro de Hacienda de la época, en su exposición de motivos al Congreso Nacional, conductas como el uso de información privilegiada o la manipulación de precios del mercado constituyen prácticas que reducen la confianza en la equidad del sistema, factor que inhibe su profundización y masificación $^{29}$. De la misma forma lo argumenta el diputado informante del proyecto al señalar que el sistema funciona sobre la base de la confianza en los instrumentos que el sistema ofrece, "en que no hay manejos raros, hay transparencia y todos los elementos indispensables para que el mercado funcione de manera adecuada" ${ }^{\prime 30}$. Esta idea es ratificada por parte de la literatura cuando señala que: "El buen funcionamiento del mercado de valores depende en gran medida en la confianza que inspire a los inversores." 31 .

Sin embargo, respecto a la configuración de la confianza, la literatura no es clara. Esto, porque lo único respecto de lo cual hay una coincidencia es en que la confianza es "la base de las relaciones humanas" y, particularmente, de las relaciones jurídico-económicas ${ }^{32}$. No obstante lo anterior, esta es entendida o como una confianza subjetiva y personalizada, es decir, como un estado psicológico "de los inversores" en orden a creer en las condiciones mínimas de participación en un sistema - así, la definición entregada por la Corte de Apelaciones de Santiago en fallo de fecha 8 de Julio de 2004 en su considerando $\mathrm{N}^{\mathbf{o}} 19$ la entiende como la generalizada convicción de tratarse de un mercado regular y confiable ${ }^{33}-$ o como una confianza institucionalizada. Esta última institucionalización de la confianza es, por ejemplo, concebida por Patricia Canales como:

"la garantía dada a estos de que negociarán en igualdad de condiciones y que estarán protegidos contra el uso ilícito de la información privilegiada, considerando que las operaciones con información de este carácter, que suponen ventajas para ciertos inversores, deterioran esta confianza y entorpecen así ese buen funcionamiento". ${ }^{34}$

\footnotetext{
${ }^{28}$ Ver Intervención Superintendente de Valores y Seguros, en: Actas de Formación de la Ley 19.301 de 1994, Sesión del Senado 15 octubre de 1993, Legislatura 327a , Extraordinaria, pp. 98 y ss.

${ }^{29}$ Ver intervención del Sr. Ministro de Hacienda Alejandro FOXLEY en: Actas de Formación de la Ley 19.301 de 1994 en Sesión del Senado 15 Octubre de 1993, Legislatura 327a , Extraordinaria, S. 20 y 21; Sesión $22^{\mathrm{a}}$, en 11 de enero de 1994, Legislatura $327^{\mathrm{a}}$, Extraordinaria, S. 14

${ }^{30}$ Ver intervención del Diputado informante señor HUEPE, Claudio en: Acta Sesión 8 de Junio de 1993; también en RIED UNDURRAGA, "Fundamentos de la Prohibición”, cit. nota n 11, pp. 449 y ss.

${ }^{31}$ CANALES, cit. nota ${ }^{\circ} 11$, p. 2.

${ }^{32}$ MONTENEGRO, Tutela penal de la Información privilegiada, cit. nota $\mathrm{n}^{\circ}$ 11, p. 42.

${ }^{33}$ Ver Sentencia de la Iltma. Corte de Apelaciones de Santiago, causa Rol N ${ }^{\circ} 7.543-2002$, de 8 de julio de 2004.

${ }^{34}$ CANALES, cit. nota ${ }^{\circ} 11$, p. 20.
} 
Polít. crim. Vol. 10, № 19 (Julio 2015), Art. 5, pp. 119-158.

[http://www.politicacriminal.cl/Vol_10/n_19/Vol10N19A5.pdf]

Si el Estado, un sistema o el cumplimiento de las normas de conductas o deberes institucionales son los garantes de dicha igualdad de oportunidades, sin embrago, tampoco queda claro y es dejado sin explicación. La diferencia entre la concepción psicológica (o interpersonal) y la institucional de la confianza (confianza sistemática) es relevante tanto desde la perspectiva de la configuración de la misma como de las formas de lesionarla. Esto, porque mientras la confianza institucionalizada es producto de la garantización de condiciones de seguridad de las relaciones interpersonales provenientes de la misma institución $^{35}$, la confianza personal y psicológica es consecuencia de la construcción interpersonal y proviene de la experiencia de una misma especie de relación afectiva y cognitiva $^{36}$.

Independiente de la configuración de la "fe pública" o la "Confianza", o psicológica (interpersonal) o institucional, esta no se explica por sí misma, concretizándose necesariamente en objetos de confianza: "en el Mercado de Valores" o en el "correcto funcionamiento del Mercado"37, en "el igual acceso a la información"38, "trato igualitario"39, "equidad del Sistema" 40 , la "transparencia e igualdad" "41 "la seguridad de tráfico jurídico"42, la seguridad en "instrumentos que se le ofrecen"43, "integridad del mercado" "44, etc. Estos objetos a que se hace referencia tanto en los motivos del legislador como en la doctrina administrativa y penal chilena, como se ha visto, designan y pretenden asegurar principalmente dos aspectos calificados de relevancia para el desenvolvimiento individual de los inversores: la igualdad de acceso a la información al momento en que se "transan los valores" y/o la transparencia, es decir, la capacidad que tiene el sistema de que toda la información esté disponible y accesible y que la información disponible se exprese en "el precio de los valores transados". Ambos elementos - según la lógica expresada y la lógica del mercado de capitales - son requeridos en momentos distintos. En otras palabras, la confianza - como bien jurídico - se construye ya sea sobre la base de una especie de "garantía" o de una "construcción afectiva interpersonalizada (no explicada en los fundamentos) - de la expectativa de todo inversor de que al momento de transar valores

\footnotetext{
${ }^{35}$ Ver JANSEN, Dorothea, "Theoriekonzepte in der Analyse sozialer Netzwerke, Entstehung und Wirkungen, Funktionen und Gestaltung sozialer Einbettung", FÖV Discussion Papers 39, Speyer, 2007. P. 23; KASSEBAUM, Ulf Bernd, (Diss) Interpersonelles Vertrauen, Entwicklung eines Inventars zur Erfassung spezifischer Aspekte des Konstrukts, Universität Hamburg, 2004, pp. 18 y ss.; LUHMANN, Niklas, Vertrauen, 4. Auflage, Lucius \& Lucius Verlag, Stuttgart, 2009, pp. 3 y ss.

${ }^{36}$ Vease en THOMAS, Alexander, "Vertrauen im interkulturellen Kontext aus Sicht der Psychologie", en: THOMAS, A. (Ed.), Die Rolle von Vertrauen in Unternehmensplanung und Regionalentwicklung- ein interdisziplinärer Diskurs. - München: Forost, Forschungsverbund Ost- und Südosteuropa, 2005, p. 19.

${ }^{37}$ Véase así también ROSAS, "El Delito de Abuso", cit. nota n ${ }^{\circ} 11$, p. 11; ONFRAY, "Ilícitos contra la información", cit. nota ${ }^{\circ} 11$, pp. 79 y ss.; MONTENEGRO, Tutela penal de la Información privilegiada, cit. nota $\mathrm{n}^{\circ} 11, \mathrm{p} .42$.

${ }^{38}$ Véase GUZMÁN ANRIQUE, Información Privilegiada, cit. nota n ${ }^{\circ}$ 11, p. 78.

${ }^{39}$ ROSAS, "El Delito de Abuso", cit. nota n ${ }^{\circ} 11$, p. 11.

${ }^{40}$ FOXLEY, Alejandro (Ministro de Hacienda), Actas de Formación de la Ley 19.301 de 1994 en Sesión del Senado 15 Octubre de 1993, Legislatura 327a, Extraordinaria, S. 20 y 21; Sesión 22a, en 11 de enero de 1994, Legislatura $327^{\text {a }}$, Extraordinaria, p. 14

${ }^{41}$ MONTENEGRO, Tutela penal de la Información privilegiada, cit. nota n ${ }^{\circ} 11$, p. 42.

${ }^{42}$ ONFRAY, "Ilícitos contra la información", cit. nota n ${ }^{\circ} 11$, pp. 79 y ss.

${ }^{43}$ HUEPE, Claudio (Diputado informante), Acta Sesión 8 de Junio de 1993; en: RIED UNDURRAGA, "Fundamentos de la Prohibición", cit. nota n ${ }^{\circ} 11$, pp. 449 y ss.

${ }^{44}$ ONFRAY, "Ilícitos contra la información", cit. nota n ${ }^{\circ} 11$, pp. 79 y ss.
} 
GARCÍA PALOMINOS, Gonzalo. "La idealización y la administrativización de la punibilidad del uso de Información Privilegiada. Un análisis de los discursos penales en la doctrina chilena”.

de oferta pública se estará en una situación de "igual acceso a la información” y, por otro lado, que en todo caso el precio con que se transa refleja toda la información disponible en el mercado. El uso de información privilegiada vendría a constituir una distorsión o disfuncionalidad que impide disfrutar de la eficiencia del sistema ideal.

Aunque no del todo autónomas a las propuestas anteriores, surgen aquellas que proponen identificar como bien jurídico sólo al "correcto funcionamiento del mercado de valores", entendido este como el funcionamiento imperfecto derivado de incumplimiento de las normas que forman el modelo ideal de funcionamiento. Así, por ejemplo, la pérdida de confianza derivada de la vulneración de expectativas de transparencia o igualdad (simetría informativa) traería como consecuencia, en palabras de María Agnes Salah, un alza del valor del capital para las compañías y una menor liquidez por la menor confluencia de inversionistas $^{45}$. Mientras que, para una segunda orientación, el efecto incidiría en mayor transparencia en el mercado de capitales ${ }^{46}$. Esta falta de transparencia, presupuesto para la eficiencia del mercado, afectaría a su vez en la correcta formación de precios ${ }^{47}$. Por su parte Alex Montenegro añade, además, que el sólo hecho de que alguien distorsione, en beneficio propio, el juego normal de las leyes del mercado, se traduciría en "una pérdida de eficiencia de éste. ${ }^{48,}$.

En consecuencia, si bien el modelo institucional mayoritario no se manifiesta uniformemente $^{49}$, lo claro es que entiende como protegido (en el ámbito económico y penal) aspectos macroinstitucionales del mercado de valores, que se verían dañados o lesionados por conductas disfuncionales a este, principalmente por la vulneración de expectativas de los inversores.

\subsection{Tensiones metodológicas: deberes negativos versus deberes positivos especiales.}

La tensión metodológica se produce entre quienes promueven una reconstrucción del injusto penal del uso de información privilegiada según la necesidad de preservar un bien jurídico institucional de conductas disfuncionales (deber negativo general) o, por el contrario, según la necesidad de "asegurar" (penalmente) la contribución o colaboración de ciertos agentes del sistema en la configuración, existencia o buen funcionamiento de la institución (deber positivo especial).

La primera de ellas, deviene de un modelo de injusto general concebido como vulneración del deber general de no dañar a otro (naeminem laedere) por medio de conductas que

\footnotetext{
${ }^{4}$ SALAH, Responsabilidad por uso de Información Privilegiada, cit. nota ${ }^{\circ}$ 11, pp. 56 y ss. (en especial p. 69).

${ }^{46}$ Intervención del Ministro de Hacienda Alejandro Foxley en: Actas de Formación de la Ley 19.301 de 1994 en Sesión del Senado 15 octubre de 1993, Legislatura 327a, Extraordinaria, S. 20 y 21; Sesión $22^{a}$, del 11 de enero de 1994, Legislatura $327^{\mathrm{a}}$, Extraordinaria, p. 14

47 RIED UNDURRAGA, "Fundamentos de la Prohibición”, cit. nota n 11, p. 452; GUZMÁN ANRIQUE, Información Privilegiada, cit. nota $\mathrm{n}^{\circ} 11$, pp. 98 y ss.

${ }^{48}$ MONTENEGRO, Tutela penal de la Información privilegiada, cit. nota ${ }^{\circ} 11$, p. 42.

${ }^{49}$ Sobre una crítica a estos conceptos ver RIED UNDURRAGA, "Fundamentos de la Prohibición", cit. nota n 11, p. 463; SALAH, Responsabilidad por uso de Información Privilegiada, cit. nota n 11, p. 215.
} 
Polít. crim. Vol. 10, № 19 (Julio 2015), Art. 5, pp. 119-158.

[http://www.politicacriminal.cl/Vol_10/n_19/Vol10N19A5.pdf]

extralimitan el ejercicio de la libertad económica - la de invertir y utilizar la información que se posee - afectando el bien jurídico representativo de la autonomía ajena, en este caso institucional. Así, por ejemplo, es el propio legislador quien de manera amplia sostiene que el aprovechamiento, conocido en nuestra historia financiera, de la situación de desequilibrio que se encuentran los inversores versus los internos del emisor, contribuye a generar desconfianza en el mercado ${ }^{50}$. Dicha explicación, sin embargo, se ha modificado con el tiempo, siendo desvinculada de la situación de "privilegio" en que se encuentran ciertos sujetos (internos) en relación al emisor, para ampliarla a todo aprovechamiento de asimetrías informativas provenientes de la posesión de información privilegiada (cuestión que queda cristalizada desde Ley 20.382 de 2009), lo que afectaría la confianza en el igual acceso a información relevante ${ }^{51}$. No obstante lo anterior, a diferencia de lo ocurrido con los modelos individualista (ej. aprovecharse de la asimetría informativa para dañar el patrimonio o propiedad de otro, ambas con tesis de fraude o de vulneración de un deber

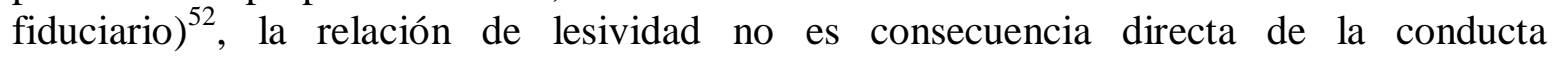
individualmente considerada, sino de un fenómeno lesivo macrosocial y acumulativo. Se trataría de conductas que representan una contribución a un fenómeno acumulativo, es decir, que asociadas a otras conductas que vulneran igualmente expectativas de simetría informativa y trasparencia - condición esencial para el funcionamiento correcto del mercado de valores - afectarían la funcionalidad del mercado de capitales ${ }^{53}$. La conducta individual y, por lo mismo, el injusto culpable sólo lo constituye un aporte a dicho fenómeno lesivo $^{54}$. El injusto es consecuencia, por lo tanto, de la vulneración del deber negativo de no ejecutar conductas dañinas para la confianza y la funcionalidad del mercado de valores.

La tesis clásica anterior entra en directa tensión con aquella que intenta reconstruir el injusto del uso de información privilegiada desde la vulneración de deberes positivos o de colaboración en un contexto institucional, particularmente del deber de contribuir o colaborar en la existencia de una igualdad de acceso a la información y, con ello, al buen funcionamiento del mercado de valores ideal. No se trata de modelos de injusto que hayan sido absolutamente desconocidos para este delito ni que surjan únicamente de alguna corriente dogmática. Ya en sus orígenes, en la interpretación de las reglas 10b y 10 b-5 de la Securities Exchange Act en Estados Unidos durante los años sesenta y setenta, se entendía que el delito no podría sino derivar de la vulneración de deberes de aportar en la

\footnotetext{
50 Informe Técnico del Ministro de Hacienda en 1981, en: RIED UNDURRAGA, "Fundamentos de la Prohibición", cit. nota ${ }^{\circ} 11$, p. 446.

${ }^{51}$ Ver BASCUÑÁN, "La regulación de la información”, cit. nota n 11 , pp. 87 y ss.

52 Para una explicación del modelo de injusto basado en el naeminem laedere ver PIÑA ROCHEFORT, “Algunos problemas del delito", cit. nota n 11, p. 119.

${ }^{53}$ FOXLEY, Alejandro (Ministro de Hacienda), Actas de Formación de la Ley 19.301 de 1994 en Sesión del Senado 15 Octubre de 1993, Legislatura 327ª, Extraordinaria, S. 20 y 21; Sesión 22a , en 11 de enero de 1994, Legislatura 327a, Extraordinaria, S. 14.

${ }^{54}$ Siguiendo la misma idea de injusto, pero diferenciado por su perspectiva de la confianza interpersonal y psicologisista, MONTENEGRO (Tutela penal de la Información privilegiada, cit. nota $\mathrm{n}^{\circ} 11$, p. 43) opta por aclarar que se trata de injustos que se explican por su capacidad para afectar "las confianzas individuales de un gran número de inversionistas". Si bien esta orientación no es desarrollada por este autor, es posible constatar que para esta concepción la "confianza" como cualidad necesaria para participar en el sistema, es un atributo personal de cada individuo y, como tal, protegido individualmente; CANALES, cit. nota $n^{\circ} 11$, pp. $^{\circ}$. 1 y 20.
} 
GARCÍA PALOMINOS, Gonzalo. "La idealización y la administrativización de la punibilidad del uso de Información Privilegiada. Un análisis de los discursos penales en la doctrina chilena”.

configuración del "Equal Access". Se trataba de la existencia de un complejo normativo compuesto por un deber positivo y uno negativo: "disclose or abstain" (divulgar o abstenerse). Vale decir, se trataría un deber del inversor de revelar a las contrapartes anónimas o divulgar al mercado información no conocida públicamente, o, en caso contrario, de abstenerse de invertir y guardar la información ${ }^{55}$, creando como efecto una garantía de igualdad en el acceso a la información relevante. Stuart Green, actualmente, intentando buscar un contenido moral del ilícito, y rechazando las tesis mayoritarias desarrolladas con posterioridad en el derecho estadounidense, señala que el uso de información privilegiada en última instancia lo que hace es violar una norma que está pensada para generar en los inversores confianza y se trataría de una forma de "trampa" más que de fraude o vulneración de deberes fiduciarios. ${ }^{56}$ Así entendido, cualquier participante en el mercado de valores es titular de dicho deber de actuar conforme a las reglas del juego lo que sería coincidente con las expectativas de igualdad indiferenciada de entre los demás inversores ${ }^{57}$.

En Chile, con una conceptualización diferente y asociado a deberes derivados de una especie de competencia institucional, Juan Ignacio Rosas ${ }^{58}$ y Juan Ignacio Piña Rochefort ${ }^{59}$ rechazan el paradigma de la agresión, mayoritario en la literatura chilena, y lo sustituyen por el paradigma del "deber de garante". Estos autores conciben el injusto como una infracción a un deber de colaboración institucional derivada de una posición especial de ciertos sujetos. Ambos autores construyen su modelo de injusto sobre la base de un supuesto deber de garante de la igualdad, con manifestación en el deber de abstención como base de la colaboración al sistema y no como manifestación de un deber negativo de no dañar a otro. En palabras de Rosas, por ejemplo, ciertos sujetos especiales se convertirían en verdaderos garantes de la igualdad de acceso a la información en atención a su posición en el emisor. Así, la libertad económica y el derecho de aprovechar en su propio beneficio las ventajas informativas de ciertos sujetos se verían limitados por el deber de salvaguardar la información relevante que se posee en atención a su posición institucional (privilegiada) y por el deber de evitar que esta sea utilizada en el mercado de valores antes que de algún modo se hubiese hecha pública. Se trata de un deber de colaboración en la configuración del mercado igualitario y funcional - producida directamente por la garantía generada por el cumplimiento de dichos deberes especiales - y surgida de la posición que ocupan ciertos sujetos. ${ }^{60}$ Así, la vulneración de tales deberes - y el incumplimiento de las expectativas normativas creadas - tendrían la capacidad de lesionar "la confianza de los inversores, y por tanto, (...) el buen funcionamiento del sistema." ${ }^{61}$. No obstante lo anterior, ni la versión de Rosas ${ }^{62}$ ni la de Piña Rochefort dan

\footnotetext{
${ }^{55}$ En nuestro país, sobre el desarrollo de la regla "disclose or abstain”, ver SALAH, Responsabilidad por uso de Información Privilegiada, cit. nota ${ }^{\circ} 11$, pp. 95 y ss.

${ }^{56}$ GREEN, Mentir, hacer trampas y apropiarse de lo ajeno, cit. nota $n^{\circ} 17$, p. 313.

${ }^{57}$ GREEN, Mentir, hacer trampas y apropiarse de lo ajeno, cit. nota $\mathrm{n}^{\circ} 17$, p. 313.

${ }^{58}$ ROSAS, "El Delito de Abuso", cit. nota n 11, pp. 16 y ss.

${ }^{59}$ PIÑA ROCHEFORT, “Algunos problemas del delito”, cit. nota n ${ }^{\circ} 11$, pp. 120 y ss.

${ }^{60}$ PIÑA ROCHEFORT, “Algunos problemas del delito”, cit. nota n ${ }^{\circ} 11$, pp. 120 y ss.

${ }^{61}$ ROSAS, "El Delito de Abuso", cit. nota n ${ }^{\circ} 11$, pp. 16 y ss.
} 
Polít. crim. Vol. 10, № 19 (Julio 2015), Art. 5, pp. 119-158.

[http://www.politicacriminal.cl/Vol_10/n_19/Vol10N19A5.pdf]

mayor explicación sobre el origen extrapenal de tales deberes (ni menos aún del círculo de destinatarios de estos) y, en realidad, más bien surge de una deducción que proviene de la norma de sanción administrativa y penal.

En consecuencia, el núcleo de lo protegido es ubicado en la desobediencia de una norma de conducta institucional y en la consiguiente defraudación de expectativas normativas, sin que una u otra sean portadoras de una especial valoración. Sin embargo, en lo que se observa una diferencia, es en que mientras Rosas reincorpora en su fundamentación el modelo clásico para justificar el merecimiento y necesidad de pena por la vinculación de la vulneración de estos deberes positivos con la lesión a la confianza y el funcionamiento del mercado de valores, la versión de Piña Rochefort, en principio, manifiesta ciertas dudas sobre la necesidad de la intervención penal, pero no así del merecimiento de pena ${ }^{63}$. En otras palabras, si bien ambas pueden justificar la necesidad de introducir una excepción a la regla general de la libertad de aprovechamiento de las ventajas informativas en el ámbito del mercado de valores - como reglas del juego necesarias para crear confianza en el sistema -, no son capaces de explicar el merecimiento y necesidad de la sanción "penal".

Corresponderá, más adelante, analizar si estas versiones son sistemáticas (por ejemplo, en relación al círculo de destinatarios de la norma de conducta y círculo de autores de los delitos), si permiten explicar la dinámica de otros mercados distintos al mercado de valores en sentido estricto, pero abarcados por la Ley $\mathrm{N}^{\circ} 18.045$ y si siguen siendo coherentes luego de la reforma a dicha ley por medio de la Ley $\mathrm{N}^{\circ} 20.382$ de 2009.

\section{Análisis crítico de los discursos penales.}

Los discursos antes analizados desarrollan justificaciones no sólo a la configuración de sistemas institucionales y su reforzamiento a través de la sanción administrativa, sino también a la criminalización y punibilidad de ciertas conductas en el marco de la interacción en instituciones económicas. Estos, tienen como puntos de partida o la existencia de instituciones económicas que reunirían ciertas características y condiciones de funcionamiento o que garantizarían expectativas normativas que justificarían la pena. Sin embargo, como se intentará explicar aquí, dichos discursos penales derivan en déficits de legitimidad ya que son incapaces de lograr una razonable reconstrucción valorativa "para el derecho penal", principalmente por su tendencia a idealizar el objeto de protección y la lesividad de las conductas: Idealización del Mercado de valores. Adicionalmente, son incapaces de proveer criterios que justifiquen la sanción penal, en el sentido explicado en la introducción, y que distingan el mero "injusto administrativo", "civil" o "económico" de un injusto penal ${ }^{64} \mathrm{y}$, como consecuencia, acepten una homologación de los fines de las distintas ramas del derecho y una administrativización del derecho penal económico.

\footnotetext{
${ }^{62}$ En la versión de ROSAS ("El Delito de Abuso", cit. nota n¹1, p. 20) es posible observar algún análisis relativo a los deberes, aunque derivados de las normas de sanción administrativas. Sin embrago, en dicho análisis queda de manifiesto la dificultad de seguir su propuesta de injusto, principalmente por la amplitud del tipo penal.

${ }^{63}$ PIÑA ROCHEFORT, “Algunos problemas del delito”, cit. nota n 11, pp. 122.

${ }^{64}$ Una crítica a las explicaciones del funcionalismo radical, ver ABANTO, Manuel, "Acerca de la teoría de bienes jurídicos”, Revista Penal, No 18 (2006), Madrid, España, p. 3, p. 31.
} 
GARCÍA PALOMINOS, Gonzalo. "La idealización y la administrativización de la punibilidad del uso de Información Privilegiada. Un análisis de los discursos penales en la doctrina chilena”.

\subsection{Idealización del Mercado de valores: ¿Una Institución homogénea?}

(a) Como ya se ha revisado, los discursos penales - principalmente de las tesis mayoritarias - se caracterizan por identificar y proponer como objeto de valoración positiva la institución "mercado de valores" como si constituyera un sistema homogéneo donde se transan unos mismos productos, con mismos niveles de organización y capacidad de funcionamiento, igual capacidad de transparencia o de garantizar unas mismas expectativas informativas como el igual acceso a la información, capacidad de formar correctamente los precios de los valores, etc. La necesidad de limitar la libertad económica así como de sancionar el aprovechamiento de ciertas ventajas informativas es planteada como una necesidad de protección general al funcionamiento mercado de valores. Así, para estas propuestas mayoritarias, se desvaloraría de la misma manera tanto la conducta de director de una compañía que se aprovecha de su ventaja informativa obtenida en una reunión de directorio y que se materializa en la venta de un porcentaje de sus acciones en la compañía, como la del trabajador del Banco Central que se aprovecha de la ventaja informativa relativa a la tasa de interés invirtiendo en derivados financieros en el mercado no organizado. Lo anterior, sin embargo, es consecuencia de una tendencia en la doctrina nacional e internacional a generalizar o idealizar el objeto de protección y, con ello, también aparentar una reconstrucción del desvalor de la conducta desde su lesividad social.

El concepto "mercado de valores" es un concepto complejo que abarca un amplio grupo de mercados, submercados, instituciones económicas, sistemas, subsistemas, mecanismos o plataformas de interacción y transacción de valores que persiguen fines y obedecen a estructuras de interacción muy disímiles. Este concepto abarca, entre otros, al llamado mercado de valores en sentido estricto que, junto al mercado de dinero, de divisas, de derivados constituyen parte del mercado financiero ${ }^{65}$. Así, mientras el mercado de valores en sentido estricto persigue "la satisfacción de la necesidad por capital de la economía o de los Estados a través reasignación del ahorro de los privados hacia los que requieren de capital necesario para desarrollar inversiones empresariales" y sus subsistemas son configurados y evaluados por su capacidad para conseguir tal objetivo (ej. Allokationsfunktion) ${ }^{66}$, el mercado de valores en sentido amplio tiene por objetivo servir al encuentro entre la oferta y demanda por dinero o títulos representativos de este, independiente del objetivo $^{67}$. No obstante lo anterior, mercados en sentido estricto o amplio, pueden estar íntimamente relacionados, como sucede por ejemplo entre el mercado de acciones o bonos y el mercado de derivados cuyo bien subyacente son dichas acciones o

\footnotetext{
${ }^{65}$ BUCK - HEEB, Petra, Kapitalmarktrecht, § 2 II, Heidelberg: C.F. Müller, 2008, número al márgen 64 y 80 y s.; GRUNEWALD, Barbara; SCHLITT, Michael, Einführung in das Kapitalmarktrecht, München: C. H. Beck Verlag, 2007, p. 1 y s; KÜMPEL, Siegfried, Bank- und Kapitalmarktrecht, Köln: Dr. Otto Schmidt Verlag, 2004, número al márgen 8.124 y s.; MERKT, Hanno; ROSSBACH, Oliver, "Zur Einführung: Kapitalmarktrecht”, JuS, 2003, München, Frankfurt a. M., pp. 217 y ss..

${ }^{66}$ PAPACHRISTOU, Marialena, Die strafrechtliche Behandlung von Börsen- und Marktpressmanipulationen, Frankfurt a. M.: Peter Lang Verlag, 2006, p. 25 y s.

${ }^{67}$ Ver LENENBACH, Markus, Kapitalmarkt- und Börsenrecht, RWS, Köln: Kommunikationsforum Verlag, 2010, número al márgen 1.5; MERKT/ROSSBACH, "Zur Einführung: Kapitalmarktrecht", cit. nota n 65, p. 217; GRUNEWALD/SCHLITT, Einführung in das Kapitalmarktrecht, cit. nota ${ }^{\circ} 65$, pp. 1 y ss.; BUCKHEEB, Kapitalmarktrecht, cit. nota n ${ }^{\circ} 65$, número al márgen 80 y s.
} 
Polít. crim. Vol. 10, № 19 (Julio 2015), Art. 5, pp. 119-158.

[http://www.politicacriminal.cl/Vol_10/n_19/Vol10N19A5.pdf]

bonos. Si esto no es así (otro bien subyacente, por ejemplo dinero), significa que dichos mercados de futuros u opciones - mercado de derivados - no se configuran (aun cuando puedan servir para eso) para servir al mismo fin ${ }^{68}$. Estos últimos reciben diferentes niveles de organización, coexistiendo en nuestro país, por ejemplo, mercados de derivados financieros - Forwards o Swaps - que operan como mercados no organizados y con valores no estandarizados ${ }^{69}$ con otros mercados de derivados estandarizados, que son transados en plataformas organizadas - como la bolsa de valores - y aseguradas por una cámara de compensación y liquidación de valores organizada, etc.

Por lo mismo, la necesidad de diferenciar entre nivel de organización, estructura y finalidad del mercado es relevante porque, si bien ya es un avance determinar la existencia de mercados informales y no organizados (ej. mercado de Swaps) respecto de los cuales no se tienen expectativas informativas relevantes (ni son garantizadas ni normativa ni estructuralmente), sin embargo, entre mercados organizados dichas expectativas informativas también pueden ser de diversa intensidad y naturaleza (ej. mercado de derivados de la bolsa de valores de Santiago y el mercado de deuda a largo plazo). En efecto, como se demostrará con relativa facilidad, la configuración normativa y estructural de cada mercado de valores cambia según los modos de interacción que el sistema busque incentivar, no siendo posible - como lo ha hecho la literatura nacional acá revisada generalizar respecto a las capacidades que se le ha querido asignar al mercado de valores, como si se tratara de un sistema único u homogéneo.

Si la finalidad del mercado de valores en sentido estricto es desarrollar sistemas alternativos al resto de los mercados financieros que faciliten eficientemente la asignación (Allokationsfunktion o allocative efficiency) de los flujos de capital de quienes tienen superávit de dinero a aquéllas empresas o personas que posean efectivamente la capacidad de desarrollar proyectos, ${ }^{70}$ su estructura dependerá de los modos de interacción que posibiliten estos fines. Para aquello, se busca implementar subsistemas que incentiven y permitan al poseedor de dinero invertir su capital con la posibilidad de devengar intereses y ganancias por sobre lo ofrecido por el sistema bancario ${ }^{71}$. El mecanismo consiste, en primer término, en la emisión - por parte de quien tiene un déficit de dinero - de participaciones (ej. acciones) en la empresa o títulos de deudas a mediano o largo plazo (ej. bonos) que son colocados en el mercado y ofrecidos a los que tienen superávit o ahorro de dinero. La estructuración en base a un mercado primario eficiente, que permita la asignación eficiente de recursos a los que realmente ofrecen mejores proyectos, no es posible sin la creación, a su vez, de un mercado secundario eficiente y confiable que le provea liquidez a dichos

${ }^{68}$ MERKT/ROSSBACH, "Zur Einführung: Kapitalmarktrecht", cit. nota ${ }^{\circ}$ 65, p. 220; WOHLERS, Wolfgang, "Kommentar § 264a", en: JOECKS, Wolfgang; MIEBACH, Klaus, Münchener Kommentar zum Strafgesetzbuch, Gesamtredaktion, München: Verlag C.H. Beck, 2006, número al márgen 24.; BUCK-HEEB, Kapitalmarktrecht, cit. nota ${ }^{\circ} 65$, número al márgen 84.

${ }^{69}$ LORENZINI, Fabiola, Futuros y Opciones, Conceptualización y Operatoria conforme a la Ley $N^{\circ} 18.045$, Santiago: Ed. Lexis Nexis, 2006, p. 18 y s.

${ }^{70}$ Ver STEINER, Manfred; BRUNS, Christoph, Wertpapiermanagement, Stuttgart, Alemania: Schäffer - Poeschel

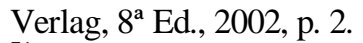

${ }^{71}$ Con más detalle ver: LONDOÑO, Fernando, "Ilícito de manipulación bursátil: fenómeno y lesividad. Aspectos de política sancionatoria", Polít. crim. Vol. 8, $\mathrm{N}^{\mathrm{o}} 15$ (Julio 2013), A3, p. 73 у ss. [http://www.politicacriminal.cl/Vol_08/n_15/Vol8N15A3.pdf] [visitado el 4.04.2014]. 
GARCÍA PALOMINOS, Gonzalo. "La idealización y la administrativización de la punibilidad del uso de Información Privilegiada. Un análisis de los discursos penales en la doctrina chilena”.

valores. Por lo mismo, este mercado configurará subsistemas, plataformas de interacción, sistemas de información y formación de precios regulados u otras unidades funcionales que permitan e incentiven esta forma de interacción ${ }^{72}$. El mercado se organizará, por lo tanto, de una manera tal de garantizar que quien dice tener la capacidad de generar proyectos (empresas o Estados), no sólo informe a su contraparte en la primera colocación de valores (mercado primario) sino que mantenga informado al mercado secundario (inversores) de su estado y de toda información que pueda ser relevante (mandatory disclosure) ya que el valor de la parte alícuota en la empresa (acción) o de la deuda de mediano o largo plazo (bonos) transada en el mercado secundario dependerá directamente de dicha información. Adicionalmente, se producirá un problema capital en este mercado, adicional a la dependencia informativa: la asimetría informativa producida tanto entre los internos al emisor, quienes ejercen funciones institucionales y el resto de los inversores. Dicha asimetría informativa es compensada institucionalmente en los mercados organizados tanto a través de la introducción de normas de conductas y sanción como a través de la configuración de subsistemas - ej. formación de precios regulada o sistemas de información formal - que facilitan la interacción igualitaria. De hecho, cuando nuestro legislador se refiere al bien jurídico protegido como la "igualdad de oportunidades", en realidad, se está refiriendo a esta necesidad. Por lo tanto, la estructura de incentivo ${ }^{73}$, principalmente del mercado secundario no es un mero producto de las interacciones informales de los inversionistas, sino de la organización e institucionalización de dicho mercado y el desarrollo de normas formales o informales de interacción ${ }^{74}$, que traen orden en el quehacer cotidiano, reduciendo o impidiendo la incertidumbre que producen las relaciones humanas $^{75}$. El contenido específico de esas normas y los fines de esas instituciones y los ámbitos de aplicación dependen y varían según el desarrollo tecnológico (técnica de la información), del entorno institucional, de las normas éticas de la sociedad, del modo de entender la institución y las interacciones, etc. ${ }^{76}$

Como se ha expuesto, paralelamente coexisten entre los mercados de valores otros igualmente organizados pero que, por perseguir fines diversos, la dependencia informativa puede manifestarse de manera diferente, lo que explica su estructura diferenciada (y no homogénea). Así, por ejemplo, el mercado de derivados recientemente organizado en la Bolsa de Santiago no se configura - aún cuando puede ser también utilizado para aquello como forma de financiamiento, sino como una forma de generar ganancias a corto plazo por medio de arbitraje o transacción simultánea en dos o más mercados o como negocio

\footnotetext{
${ }^{72}$ LIEBEL, Hermann, Täter - Opfer - Interaktion bei Kapitalanlagebetrug, Neuwied: Luchterhand Verlag, 2002, p. 12.

${ }^{73}$ Sobre la teoría de los sistemas y el concepto de sistema en el mercado de valores ver PEETZ, Dietmar, Hedge-Fonds und Finanzmarktinstabilität, Trabajo Doctoral en Universität Kassel, p. 90 y ss.

${ }^{74}$ NEE, Victor; INGRAM, Paul, "Embeddedness and Beyond: Institutions, Exchange, and Social Structure", en: BRINTON, M.; NEE, V. (Eds.), The New Institutionalism in Sociology, New York: Stanford University Press, 2002, p. 19.

${ }^{75}$ RICHTER, Rudolf; FURUBOTN, Eirik, Neue Institutionenökonomik, $3^{\mathrm{a}}$ Ed., Tübingen: Mohr Siebeck, 2003, p. 97 y ss.

${ }^{76}$ RICHTER/FURUBOTN, Neue Institutionenökonomik, cit. nota nº 75, p. 346.
} 
Polít. crim. Vol. 10, № 19 (Julio 2015), Art. 5, pp. 119-158.

[http://www.politicacriminal.cl/Vol_10/n_19/Vol10N19A5.pdf]

especulativo de las fluctuaciones de precios. $^{77}$ Así entendido, en dicho mercado de derivados organizado, no sólo las expectativas de seguridad, sino que además la dependencia informativa es diversa. Esto, porque la dependencia informativa relevante depende principalmente del mercado del bien subyacente, en circunstancias que la parte de la dependencia informativa relativa al emisor y tenedor (riesgo de incumplimiento o de crédito de la contraparte) es compensada institucionalmente sea por la Cámara de Compensación (que actúa como contraparte obligada) y que elimina el riego de incumplimiento y por las garantías exigidas al emisor antes de transar (depósitos en garantía) $^{78}$.

Las expectativas informativas son absolutamente diferentes entre ambos mercados organizados y el posible entendimiento del uso de información privilegiada en este ámbito se puede volver superfluo o, al menos, exigiría que la fuente de la información privilegiada se extienda dudosamente al mercado del bien subyacente ${ }^{79}$.

Adicionalmente, y como ya se ha adelantado, bajo el concepto de "mercado de valores" coexisten también distintos sistemas de interacción económica, no sólo con finalidades económicas distintas y que desarrollan modos de interacción heterogéneos, sino informales y no organizados (aunque supervigilados). Estos se caracterizan porque los agentes que transan valores en él no necesariamente lo hacen sirviéndose de una institucionalidad o sistemas que sean capaces de garantizar niveles de seguridad, de veracidad de la información, formaciones reguladas de precios. En otras palabras, estas otras formas de interacción, aun cuando también son mercado de valores, no siempre estarán en condiciones de garantizar expectativas o las mismas expectativas informativas y, por lo mismo, parece también superfluo hablar respecto de ellos de una misma forma de funcionamiento eficiente o de igualdad de acceso a la información, transparencia o eficiencia en la formación de precios, etc. Esto sucedería, por ejemplo, con el mercado de Swaps o Forwards no organizado en nuestro país, para quienes el único sistema de resguardo es el sistema de justicia civil (y últimamente una industria del seguro desarrollada $)^{80}$. Así, en estos ámbitos no parece coherente seguir sosteniendo que la prohibición del uso o divulgación de información privilegiada es consecuencia del deber de no dañar la confianza en el correcto funcionamiento del mercado de valores o el funcionamiento mismo como tampoco la confianza en la igualdad de acceso a la información relevante.

\footnotetext{
${ }^{77}$ MERKT/ROSSBACH, “Zur Einführung: Kapitalmarktrecht", cit. nota ${ }^{\circ}$ 65, p. 220; WOHLERS, "Kommentar § 264a", cit. nota $\mathrm{n}^{\circ}$ 68, número al margen 24; BUCK - HEEB, Kapitalmarktrecht, cit. nota ${ }^{\circ}$ 65, número al margen 84; en el caso particular del mercado de derivados de la Bolsa de Valores de Santiago, se expresa explícitamente estos fines: ver en http://www.bolsadesantiago.com/theme/derivadosLista.aspx

${ }_{78} \mathrm{Al}$ respecto ver LORENZINI, Futuros y Opciones, cit. nota n ${ }^{\circ} 69, \mathrm{pp} .78$ y ss.

${ }^{79}$ Es tan cierto lo anterior, que la Directiva sobre insiders trading 2003/6/CE del Parlamento europeo y del Consejo de 28 de enero de 2003, sobre las "Operaciones con información privilegiada y la manipulación del mercado", tuvo que ser modificada por la Directiva 2008/26/CE, de 11 de marzo de 2008 en el sentido de hacerla compatible con el mercado de derivados.

${ }^{80}$ De esta misma forma parece entender la SVS, que en un apartado bajo el subtítulo "Precauciones y advertencias" relativas a los riesgos de invertir en Derivados ofrecidos en mercados regulados en nuestro país, ver: http://www.svs.cl/educa/600/w3-propertyvalue-562.html
} 
GARCÍA PALOMINOS, Gonzalo. "La idealización y la administrativización de la punibilidad del uso de Información Privilegiada. Un análisis de los discursos penales en la doctrina chilena”.

(b) Lo dicho anteriormente es esencial en el análisis crítico de la reconstrucción valorativa desde la lesividad de la conducta que debemos emprender a propósito de los delitos de uso y divulgación de información privilegiada. Esto, porque, como se ha visto, no todos los modelos propuestos en los discursos penales se desarrollan en torno a deberes negativos y/o positivos concretos (y que tienen la capacidad de identificar un mercado específico), sino, más bien todo lo contrario. En sus propuestas de bien jurídico y de aproximación a la relación de lesividad social como fuente del deber negativo, sólo es posible extraer una concepción "idealizada" y "homogénea" del mercado de valores. Esto, no obstante la realidad demuestra un ámbito de interrelaciones absolutamente heterogéneo, con niveles de dependencia informativa diferente y con niveles de organización donde ni la manipulación de precios ni el uso de información privilegiada tienen un mismo sentido.

El problema se produce, entonces, si consideramos que ni las normas de conductas extrapenal, ni los tipos penales, ni las normas generales que fijan el marco regulatorio general de la Ley $\mathrm{N}^{\circ} 18.045$ (LMV) parecen definir o limitar en ámbito de relaciones económicas donde tiene sentido la existencia de la prohibición (o el deber) y la norma de sanción:

En efecto, mientras el art. 1 de la LMV señala en términos generales que a las disposiciones de dicha ley queda sometida la oferta pública de valores y sus respectivos mercados e intermediarios - incluyendo los mercados secundarios de dichos valores dentro y fuera de las bolsas -, el art. 3 ejemplifica dichos productos como cualquier título transferible incluyendo acciones, opciones a la compra y venta de acciones, bonos, debentures, cuotas de fondos mutuos, planes de ahorro, efectos de comercio y, en general, todo título de crédito o inversión. La única excepción la constituyen "los valores emitidos o garantizados por el Estado, por las instituciones públicas centralizadas o descentralizadas y por el Banco Central de Chile". En otras palabras, el ámbito de aplicación de las normas de conducta y normas de sanción abarca a una gran cantidad de mercados, respecto de los cuales las tesis mayoritarias demandan transparencia o igualdad o, lo que es aún más extremo, dicen proteger fe pública, confianza en la transparencia, confianza en la igualdad de acceso a la información, etc.

A esto se suma el hecho que la técnica legislativa utilizada en el Art. 60 e), g) y h) de la LMV, demanda una concreción por parte del aplicador del derecho y, por lo mismo, el desarrollo de criterios de imputación penal razonables. Esto, porque ninguno de los tipos penales ni los conceptos utilizados en su configuración, permiten seleccionar con meridiana claridad de entre los injustos administrativos aquellos cualificados de relevancia penal ${ }^{81}$. Cuestión diversa sucede, por ejemplo, en el parágrafo §38 Abs.1 en relación con el parágrafo $§ 14 \mathrm{WpHG}$ alemana (Ley de comercio de valores), en que la técnica legislativa le permite definir expresamente el ámbito de aplicación del tipo penal de uso de información privilegiada. Estas, a diferencia de las normas administrativas, limitan la aplicación de la norma de sanción penal a transacciones en mercados de valores o plataformas (ej. bolsas de comercio) reguladas, medianamente regulados y supervigilados ya sea por la Bundesanstalt

\footnotetext{
${ }^{81}$ Aquí sólo es evidente que el legislador ha querido dejar fuera de los injustos penales aquel referido a la
} omisión. 
Polít. crim. Vol. 10, № 19 (Julio 2015), Art. 5, pp. 119-158.

[http://www.politicacriminal.cl/Vol_10/n_19/Vol10N19A5.pdf]

für Finanzdienstleistungsaufsicht o Bafin (equivalente funcional de la SVS) o la Börsenaufsichtsbehörden o BAD (institución pública que supervigila el funcionamiento de las Bolsas de comercio), ya que son los únicos que pueden asegurar o garantizar altos niveles de transparencia, formación regulada de precios y acceso igualitario a la información y, por lo mismo, los únicos respecto de los cuales se puede hablar de correcto funcionamiento de un sistema o de confianza en igualdad de acceso a la información. A diferencia de la técnica legislativa en la legislación alemana, en el caso chileno es el aplicador del derecho el que se ve obligado a concretizar los ámbitos en que tiene sentido la aplicación de una sanción penal.

Esta técnica legislativa obedece, sin embargo, al nivel de complejidad del mercado alemán. Así, por ejemplo, en mercados más complejos y amplios como ese, se configuran mercados con distintos objetivos y con distintos niveles de organización y protección. De esta manera, mientras el mercado de valores en sentido estricto (mercado de capitales) esta intensamente regulado, organizado, supervigilado y tiene como objetivo la participación de amplios sectores de la población y, por lo tanto, recibe mayor protección, se reconocen mercados de valores carentes de dicha regulación u organización (Ej. Grauer Kapitalmarkt). En estos, ni se transan necesariamente títulos estandarizados ni son supervigilados por la Bafin, permitiendo una mayor tendencia a la especulación (menos dependencia informativa) y los inversores reciben menor protección. El objetivo, sin embargo, de esta escasa regulación dice relación con que en dichos segmentos participan únicamente especuladores o inversores profesionales que pueden interactuar en ámbitos más riesgosos, menos protegidos, pero más baratos y con mayores posibilidades de ganancia $^{82}$. Se trata, en general, de mercados de fondos inmobiliarios cerrados, de metales, de piedras preciosas y, sobre todo, de futuros ${ }^{83}$. Este ámbito, sólo excepcionalmente es abarcado por las normas de sanción penal y en la medida que afecte la formación de los precios en los mercados organizados.

Si bien en Chile la situación no es similar, sin embargo, durante los últimos años el mercado ha tendido a complejizarse y a desarrollar segmentos sólo meridianamente supervigilados, pero no institucionalizados ni organizados. Por lo mismo, el problema de la generalización e idealización (homologación) del bien jurídico también se presenta en Chile, no obstante pueda tener todavía menor importancia práctica. Esto, porque el mercado de valores chileno es mucho más pequeño $\mathrm{y}$, por lo mismo, intensamente formal, regulado y organizado, existiendo pocos ámbitos que no estén sujetos al control de la Superintendencia de Valores y Seguros (Art. 4 LMV), con excepción de determinadas transacciones privadas ${ }^{84}$. No obstante lo anterior, la orientación a la protección de ámbitos generales de interacción, (como el mercado de valores o el mercado financiero) sin identificar sistemas, plataformas o mecanismos de interacción, así como la generalización de sus cualidades (confianza, transparencia, etc.), no permiten solucionar problemas penales, por falta de concretización de la lesividad.

\footnotetext{
${ }^{82}$ Sobre la inseguridad de dichos mercados véase HAGEMANN, Michael H., Grauer Kapitalmarkt und Strafrecht, Osnabrück: V\&R unipress GmbH, 2005, p. 146.

${ }^{83}$ véase en HAGEMANN, Grauer Kapitalmarkt, cit. nota ${ }^{\circ} 82$.

${ }^{84}$ Véase NOVOA, Raúl; NOVOA, Gabriela, Derecho de Mercado de Capitales, Santiago: Editorial Jurídica de Chile, 1995, pp. 58 y ss.
} 
GARCÍA PALOMINOS, Gonzalo. "La idealización y la administrativización de la punibilidad del uso de Información Privilegiada. Un análisis de los discursos penales en la doctrina chilena”.

El problema tampoco es solucionado por los posibles límites que podrían surgir de las normas de conducta pre o extrapenal referidas al uso de información privilegiada (art. 164 y ss. LMV) que, de algún modo, podrían fijar un ámbito de especial aplicación. Sus formulaciones son tan difusas, que tanto desde la perspectiva del círculo de destinatarios de la norma como del ámbito de aplicación económica, pueden ser interpretadas abarcando, en sentido amplio, todo tipo de mercado de valores o, en sentido estricto, sólo el mercado de valores en sentido estricto. Así, por ejemplo, si la tesis de Antonio Bascuñán es correcta en tanto entiende que con la Ley $\mathrm{N}^{\circ} 20.382$ de 2009 se optó por el modelo de la "posesión" de información (en razón de su cargo, posición, actividad o relación) como generador de deberes en perjuicio del de la "posición privilegiada" en el emisor, y más aún, si desde el concepto de información privilegiada se acepta información no proveniente del emisor, es posible extraer del círculo de destinatarios una idea muy amplia del ámbito o mercados cubiertos por la norma ${ }^{85}$. Mientras que, por el contrario, de la indeterminación de esa norma también es posible una interpretación más restrictiva, como la sostenida por María Fernanda Vásquez Palma, desde el modelo de la "posición privilegiada" que interpreta la cláusula "cargo, posición, actividad o relación" desde una perspectiva "societaria" y limitando la fuente de la información al emisor. Con ello, restringe la interpretación de las normas a una lógica propia del mercado de valores en sentido estricto (compañía o empresa/valores representantes de alícuota o deuda a largo plazo $)^{86}$ y la excluye de mercados como el de derivados.

Las tesis institucionales relativas a la lesividad social de las conductas propuestas por la doctrina, por lo tanto, no logran solucionar este problema ni proveen criterios de concreción de lesividad que expliquen la desvaloración de la conducta (ni menos de imputación personal de injustos culpables) que demanda la técnica de tipificación utilizada. La falta de concreción en la realidad social, sus altos niveles idealización y su tendencia a utilizar conceptos generalizantes atentan contra dicho cometido. Por ahora, para la literatura mayoritaria, parece indiferente si se abarcan mercados regulados pero carentes de sistemas formales de acceso a la información, o institucionalizados de formación de precios (ej. nuestro mercado de acciones o bonos) $\mathrm{u}$ otros en que, no obstante estar meridianamente regulados, carecen de sistemas formales de interacción (ej. nuestro mercado de derivados no organizado). También parece ser indiferente, la necesidad de la expectativa concreta en este caso, por ejemplo, el igual acceso a la información - en el contexto de interacción (mercado concreto).

\section{2. ¿El injusto del delito de Uso de Información Privilegiada como mera trampa a las reglas del juego o como lesión a subsistemas regulados?}

Según lo ya señalado, parte importante de los problemas surgidos de los discursos penales referidos al uso de información privilegiada están radicados en que han enfrentado su análisis desde una perspectiva general e idealizada, desatendiendo la configuración real del mercado de valores (institucionalizado). Sin embargo, entender correctamente la finalidad de las normas de conductas y de sanción en su contexto institucional real sólo se logra

\footnotetext{
${ }^{85}$ BASCUÑ̂́N, "La regulación de la información”, cit. nota n 11, pp. 121 y ss.

${ }^{86}$ VÁSQUEZ PALMA, "Revisión del ámbito de aplicación”, cit. nota n 11, pp. 271 y ss.
} 
Polít. crim. Vol. 10, № 19 (Julio 2015), Art. 5, pp. 119-158.

[http://www.politicacriminal.cl/Vol_10/n_19/Vol10N19A5.pdf]

atendiendo al modelo de mercado ideal que se busque cristalizar y las formas de interacción económica que se busquen privilegiar institucionalmente. El análisis de dichos modelos ideales y su relación con la prohibición del uso de información privilegiada puede dar luces a los problemas planteados en este trabajo. Esto, porque en general, la utilización de información privilegiada no constituye per se una conducta desvalorada en las transacciones privadas y en los mercados, como sucedería, por ejemplo, entre quien vende un auto (y conoce la historia de vehículo) y quien lo compra ${ }^{87}$.

Así, por ejemplo, el modelo neoclásico - restringido, por cierto, a los mercados regulados y organizados - basa el entendimiento del mercado de capitales eficiente bajo el prisma del "inversor racional ${ }^{88 "}$. Bajo este modelo se tenderá a configurar sistemas y unidades funcionales que llenen las expectativas del paradigma de la racionalidad (homo economicus), en la idea que los inversores poseen un entendimiento del riesgo de sus decisiones. Por lo mismo, las expectativas normativas en estos sistemas dicen relación con que su éxito es el resultado del esfuerzo por lograr la maximización de la utilidad esperada $^{89}$. Este modelo ha servido de base para el desarrollo de importantes teorías económicas así como de modelos financieros que permiten explicar el comportamiento de los inversores y los precios en el mercado ${ }^{90}$. Así, por ejemplo, la teoría de eficiencia informativa de Eugene Fama que defiende la idea de que un mercado eficiente se caracteriza por el hecho de que toda la información será procesada de inmediato en los precios $^{91}$. Siguiendo estas teorías, se tenderá a configurar institucionalmente un mercado que provea sistemas de flujos de información eficiente y sistemas de formación de precios que puedan cumplir su función de asignación del capital ${ }^{92}$. Por lo mismo, bajo esta idea se introducen normas de comportamiento que establezcan importantes deberes de información, de inscripción en diferentes registros, y, al mismo tiempo, coordina dichos deberes con la implementación de sistemas de flujo información públicos y privados, supervigilancia privada (regulación de la auditoría externa de las empresas) y pública (SVS), etc., logrando mayor eficiencia informativa ${ }^{93}$. Sólo de esa forma, se podría

\footnotetext{
${ }^{87}$ Ver CICERÓN, Obras Completas, cita nota ${ }^{\circ} 14$.

${ }^{88}$ Ver en general RICHTER/FURUBOTN, Neue Institutionenökonomik, cit. nota $\mathrm{n}^{\circ} 75$; en particular PICOT, Arnold; DIETL, Helmut, „Informations(de-)regulierung am Kapitalmarkt aus institutionenökonomischer Sicht“, en: SCHENK, E.; SCHMIDTCHEN, D. (Hrsg.), Neue politische Ökonomie der Regulierung, Deregulierung und Privatisierung, Bd. 13, Jahrbuch für neue politische Ökonomie, Tübingen: Mohr Siebert, 1994, pp. 113 y ss; en relación a los modelos informativos ver FILIPIUK, Bogna, Transparenz der Risikoberichterstattung, Wiesbaden: Gabler Ed. Wissenschaft, 2008, p. 76.

${ }^{89}$ Ver FILIPIUK, Transparenz der Risikoberichterstattung, cit. nota $\mathrm{n}^{\circ} 88$, pp. 78 y ss. (en especial p. 83).

${ }^{90}$ FILIPIUK, Transparenz der Risikoberichterstattung, cit. nota ${ }^{\circ}$ 88, pp. 78 y ss.

${ }^{91}$ Con amplia literatura al respecto FILIPIUK, Transparenz der Risikoberichterstattung, cit. nota $n^{\circ} 88, \mathrm{p}$. 84; en la literatura chilena véase ZARHI, Oscar, "La teoría de los mercados eficientes como garantía de una correcta fiscalización del mercado de valores", en: GONZÁLEZ, Marco (Ed.), Regulaciones en el mercado de valores, Cuadernos de Extensión Jurídica N 19, Santiago: Universidad de los Andes (Chile), 2010, pp. 43 y ss.

${ }_{92}$ Véase detalladamente PERRONE, Andrea, "Información en el mercado de valores y tutela del inversor", Polít. Crim. Vol. 4, $\mathrm{N}^{\mathrm{o}} 7$ (Julio 2009), Art. 7, pp. 197-229 (1-33) p. 11. [http://www.politicacriminal.cl/Vol_04/n_07/Vol4N7A7.pdf] [visitado el 04/04/2014]; FILIPIUK, Transparenz der Risikoberichterstattung, cit. nota $\mathrm{n}^{\circ}$ 88, p. 85 y s.

${ }^{93}$ FAMA, Eugene, "Efficient Capital Markets: A Review of Theory and Empirical Work", Journal of Finance, Vol. 25, (2), 1970, p. 387; FILIPIUK, Transparenz der Risikoberichterstattung, cit. nota ${ }^{\circ}$ 88, p. 86 ys.
} 
GARCÍA PALOMINOS, Gonzalo. "La idealización y la administrativización de la punibilidad del uso de Información Privilegiada. Un análisis de los discursos penales en la doctrina chilena”.

configurar un sistema de interacción que le permitiera al partícipe llenar las expectativas del paradigma de la racionalidad.

Bajo un sistema de estas características se intentará, por consecuencia, eliminar toda conducta que resulte distorsionadora o disfuncional para dichos fines y que desincentive este especial modo de interacción, vale decir, principalmente aquellas conductas que impiden o distorsionen la eficiencia informativa condición necesaria para un inversor racional. Con el objetivo de garantizar el funcionamiento de sistemas que ofrecen eficiencia informativa se introducen, junto a los deberes positivos de información o de abstención (, entre otros,) normas de conducta prohibitivas dirigidas, en primer lugar, a todos los sujetos que participan en el flujo de información y, en segundo, a todos los participantes del sistema. Así, por ejemplo, mientras la prohibición de presentar de información errónea o falsa al mercado o la prohibición de manipular los precios o de desarrollar conductas meramente especulativas es de carácter general, también se introducen prohibiciones especiales tales como la prohibición de certificar falsamente información contable ${ }^{94}$. Dichas normas de conductas positivas y/o negativas, así como los sistemas creados por ellas, se ven, por su parte, reforzadas por normas de sanción que cumplen un rol configurador: proteger la funcionalidad del sistema y, en especial, la eficiencia informativa de los subsistemas concretos $^{95}$. En este modelo, el injusto del uso de información privilegiada sólo se puede entender desde perspectivas que se orienten a proteger dichos sistemas informativos concretos - no meras normas de conducta aisladas - que garantizan ciertas expectativas informativas de los participantes en el mercado (como la igualdad en el acceso a información con contenidos garantizados de seriedad o el sistema de formación de precios) que se ven afectados por el uso de dicha clase de información. La relevancia del desvalor de la conducta radicaría, entonces, en la capacidad de afectar un subsistema organizado y regulado (aquí juegan un rol configurador las normas de conducta) - por ejemplo, los subsistemas informativos o sistemas formales de formación de precios - que posibilitan el ejercicio de libertades económicas de un homo economicus y no en la mera vulneración de una "regla de juego".

No sucede lo mismo con el modelo neoinstitucional o teoría de las instituciones económicas, ya que tiende a desmitificar la idea del inversor racional y pone el acento en los comportamientos y relaciones de los participantes en el mercado y entre estas y las

\footnotetext{
${ }^{94}$ Así, por ejemplo, y refiriéndose al delito de manipulación de precios, LONDOÑO ("Ilícito de manipulación bursátil", cit. nota ${ }^{\circ} 71$, p. 118.) destaca, por un lado, un ámbito de interés propio del modelo neoclásico y su modelo de racionalidad (señalando que la prohibición obedece a un criterio de conservación de los atributos del mercado bursátil, así como ha sido diseñado originalmente(...) como un sistema en el que los participantes se esfuerzan por conocer o anticipar el valor actual y potencial de los bienes intercambiados, de manera de poder maximizar las utilidades de las operaciones y de la inversión en general") y, por otro, destaca su manifestación neoinstitucional ("su lesividad ha sido ya puesta en evidencia: la alteración de las condiciones de paridad, el incremento del riesgo de desviación en la eficiente distribución de los recursos, el detrimento de la confianza y, con todo ello, la eventual disminución del volumen y liquidez del mercado). Con esto este autor capta correctamente que la formulación de nuestras normas tienen un contenido ecléctico, que contiene ambos aspectos en su valoración.

${ }_{95}$ Véase por ejemplo, LONDOÑO, "Ilícito de manipulación bursátil”, cit. nota n 71, pp. 64 y ss.
} 
Polít. crim. Vol. 10, № 19 (Julio 2015), Art. 5, pp. 119-158.

[http://www.politicacriminal.cl/Vol_10/n_19/Vol10N19A5.pdf]

normas de conducta y expectativas de éstos en el mercado ${ }^{96}$. En efecto, autores como Sanford Grossmann o Joseph Stiglitz - representantes de esta perspectiva teórica describen la idea del mercado eficiente simplemente como una mera paradoja ${ }^{97}$. Esta teoría, como ya se adelantó, incluye aspectos institucionales del mercado que suelen ser ignorados por las teorías neoclásicas, tales como los costos de transacción ${ }^{98}$, la formación de los inversores, los sistemas de control, la confianza en el sistema, etc. ${ }^{99}$ Por lo mismo, esta teoría se concentra en las dificultades que resultan de la interacción y que se presentan como problemas de motivación y coordinación en un sistema configurado como "de incentivo" $" 100$. Esta nueva perspectiva sigue la idea de que los actores o participantes del sistema se caracterizan por su comportamiento oportunista y, por lo mismo, normalmente están dispuestos a no informar o informar incompletamente a la contraparte ${ }^{101}$. El modelo de mercado, bajo la influencia de estas teorías, concentra sus esfuerzos en la coordinación de personas como solución del problema de la interacción y, por lo mismo, la regulación se concentra en proveer coordinación y disminuir los costos de transacción ${ }^{102}$.

Bajo este modelo, la necesidad de configurar sistemas y la introducción de normas de conductas y sanción sufren sino un cambio, al menos una ampliación relevante. Así, por ejemplo, la manipulación de mercado o de precios así como la presentación de información falsa, no son conductas solamente desvaloradas porque afectan el funcionamiento de un subsistema informativo determinado, sino en razón que afectan la necesaria confianza de los partícipes e inversores en ese mercado. Lo anterior es relevante si se piensa en que un sistema poco confiable será abandonado por dichos inversores, perjudicando su liquidez ${ }^{103}$ $\mathrm{y}$, con ello, elevando los costos de transacción. Bajo la configuración de un mercado de valores basado en este modelo ideal, el uso de información privilegiada posiblemente encontrará su justificación y su desvaloración en la capacidad de lesionar la macrofuncionalidad de una institución "organizada", evitando orientarse a sus microestructuras o sistemas que posibilitan la interacción. En efecto, la literatura que apoya la configuración del mercado según este modelo ideal ha intentado demostrar que, en la realidad, las conductas de abuso de información privilegiada, desde el punto de vista de la eficiencia informativa, están lejos de ser un factor distorsionador para los sistemas de formación de precios, ya que, si bien influye en estos, incluso tiene la capacidad de reflejar

\footnotetext{
96 Ver PICOT/DIETL, „Informations(de-)regulierung am Kapitalmarkt““, cit. nota n 88, pp. 113 y ss.; FILIPIUK, Transparenz der Risikoberichterstattung, cit. nota $\mathrm{n}^{\circ} 88$, pp. 76 y ss.

${ }^{97}$ GROSSMAN, Sanford J.; STIGLITZ, Joseph, "Information and Competitive Price Systems", American Economic Review, 66 (2), 1976, pp. 246 y ss.; FILIPIUK, Transparenz der Risikoberichterstattung, cit. nota $\mathrm{n}^{\circ} 88, \mathrm{p} .88$.

98 Véase RICHTER/FURUBOTN, Neue Institutionenökonomik, cit. nota n 75, p. 341: "Mientras más grande el grupo de actores en el mercado, mucho menores los costos de utilización del mercado".

99 NORTH, Douglass, "Institutions", Journal of Economic Perspectives, vol. 5, N 1 (1991), pp. 97 y ss.; FLEISCHER, Holger, "Grundfragen der ökonomischen Theorie im Gesellschafts- und Kapitalmarktrecht", Zeitschrift für Unternehmens- und Gesellschaftsrecht, Band 30, Heft 1, 2001, p. 1 y ss.

${ }^{100}$ FILIPIUK, Transparenz der Risikoberichterstattung, cit. nota ${ }^{\circ} 88$, pp. 94 y ss.

${ }^{101}$ FILIPIUK, Transparenz der Risikoberichterstattung, cit. nota ${ }^{\circ}$ 88, p. 94.

102 GIL, Javier Alfonso, "Instituciones económicas: contornos de triada básica”, Revista Economistas, Nr. 73, 1997, pp. 128 y ss.; FILIPIUK, Transparenz der Risikoberichterstattung, cit. nota n 88, p. 94.

${ }^{103}$ A modo de ejemplo, véase en materia penal LONDOÑO, "Ilícito de manipulación bursátil", cit. nota ${ }^{\circ}$ 71, p. 118.
} 
GARCÍA PALOMINOS, Gonzalo. "La idealización y la administrativización de la punibilidad del uso de Información Privilegiada. Un análisis de los discursos penales en la doctrina chilena”.

una información no conocida rápidamente en los mismos ${ }^{104}$. Aun cuando lo anterior no es del todo claro y merece ser investigado con mayor precisión, parte de la literatura opta por entender la desvalorización de estas conductas por la capacidad de afectar las expectativas de igualdad de oportunidades o de acceso a la información de los inversores, no necesariamente garantizadas, cuestión que afectaría las funciones que se le asigna al mercado.

Este modelo neoinstitucional es tan amplio, para la perspectiva penal, que es capaz - sin mucho esfuerzo - de albergar tesis tan disimiles como el paradigma de la "trampa" de Stuart Green ${ }^{105}$, el paradigma de la "agresión" al funcionamiento del mercado de valores y a la "confianza en la igualdad de acceso a la información" (defendido en Chile o Alemania) ${ }^{106}$ y el paradigma del "deber de garante" representado en Chile por Rosas y Piña Rochefort. Mientras los dos primeros paradigmas tienen la capacidad de abarcar una gran cantidad de submercados de valores comprendidos por los arts. 1 y 3 de la LMV y ser coherente con la amplitud del círculo de destinatarios de la norma de conducta según la nueva estructura normativa del art. 165 y ss. de la Ley $\mathrm{N}^{\circ} 18.045$ (luego de su modificación por la Ley $\mathrm{N}^{\circ} 20.382$ de 2009) ${ }^{107}$, sin embargo, adolece de sólo poder dar cuenta de la necesidad de regular el mercado de valores en sentido estricto. La interrogante sobre el "merecimiento de pena" y la necesidad de proveer criterios para la "reconstrucción del injusto penal" cualificado, como se verá, queda sin respuesta. Por su parte, el tercero - el paradigma del "deber de garante" - tiene la capacidad de reducir la aplicación del tipo penal a ámbitos regulados y organizados y, adicionalmente, tiene la capacidad de identificar - al menos teóricamente - deberes positivos configuradores de la institución del mercado de valores. Sin embargo, para el caso chileno, no tiene la capacidad de explicar la "incoherencia" (asistematicidad) que se produce entre su propuesta y el círculo de destinatarios de las normas de conductas y sujetos activos de la norma de sanción penal. Menos aún puede justificar que la vulneración de un deber de solidaridad surgida de una norma reguladora del mercado, pueda o tenga la capacidad de explicar adecuadamente la diferencia entre un injusto administrativo de uno penal. Lo anterior no es sino consecuencia de la incapacidad de fundamentar correctamente el injusto penal. En lo que sigue se profundizará particularmente en esta tendencia, casi absoluta de los discursos penales nacionales, por el modelo neoinstitucional para explicar la criminalización y reconstruir el injusto penal.

\subsection{Resultado 1: Administrativización del derecho penal económico.}

\subsection{1. ¿Protección de las "ficciones necesarias"?}

\footnotetext{
${ }^{104}$ FILIPIUK, Transparenz der Risikoberichterstattung, cit. nota ${ }^{\circ} 88$, p. 86; en la literatura chilena ZARHI, "La teoría de los mercados eficientes", cit. nota n 91 , pp. 54 y ss.

${ }^{105}$ GREEN (Mentir, hacer trampas y apropiarse de lo ajeno, cit. nota $\mathrm{n}^{\circ} 17$, p. 313 y ss.) señala que se trata de una violación de reglas del juego que, en última instancia, están pensadas para generar en los inversores la confianza de que están jugando en forma justa.

${ }^{106}$ Véase al respecto en GARCIA PALOMINOS, "Modelo de protección”, cit. nota n 11, pp. 23 y ss.

${ }^{107}$ Véase al respecto BASCUÑ̂́N, "La regulación de la información”, cit. nota n 11, pp. 121 y ss.
} 
Polít. crim. Vol. 10, № 19 (Julio 2015), Art. 5, pp. 119-158.

[http://www.politicacriminal.cl/Vol_10/n_19/Vol10N19A5.pdf]

Piña Rochefort utiliza el concepto "ficciones necesarias" para explicar la idea de que al derecho penal le corresponde proteger o colaborar en la producción del modelo ideal creador de expectativas normativas en el ámbito del mercado de valores (entendido, eso sí, como homogéneo). Dichas expectativas ideales - que para el delito de uso de información privilegiada consistiría en contar con una caudal de información "relativamente simétrico" para las decisiones de inversión - no constituirían una realidad. En efecto, frente a la necesidad de explicar la configuración de dicha expectativa y razón de ser para la norma de conducta, sostiene, al contrario de lo esperado, que dicha expectativa institucional estaría basada en una especie de ficción de relativa igualdad de oportunidades y simetría informativa ${ }^{108}$. En otras palabras, no se trataría de una expectativa basada en la realidad social, es decir, garantizada por un subsistema informativo de algunos de los mercados de valores organizado. Por lo mismo, y para lo que nos interesa, no se requeriría un análisis de la verdadera organización de los sistemas de interacción y su capacidad para funcionar de determinada manera o para garantizar determinada expectativa, sino simplemente se trata de una "ficción necesaria". Esta, no obstante no estar cristalizada en sistemas, si merece de protección penal por ser garantizada normativamente. Así, como se vio, siguiendo este autor a Percy García Cavero, la confianza se protegería no por su valor intrínseco, sino por cuanto el propio macro-sistema (la institución) se ha configurado sobre la base de ella. Por lo mismo, lo verdaderamente relevante sería que en la actual configuración su funcionamiento correcto dependería de que los actores puedan confiar en la relativa igualdad de oportunidades y de información, cuestión garantizada por deberes especiales y positivos en razón de la posición que ocupan ciertos sujetos.

Esta opinión, coincide con una tesis común en la literatura mayoritaria ${ }^{109}$ y que acepta que la igualdad de condiciones no es o no tiene una manifestación en la realidad social. Frente a esa "natural" e, incluso, a veces legítima asimetría en la información (por ejemplo, entre quien crea información y los demás inversores), la aquí revisada dogmática penal chilena ha aceptado que la limitación de dicha libertad económica (y de aprovechamiento de las ventajas informativas), por medio de normas de conducta y de sanción, estaría justificada en la idea de "colaborar" en la producción de una "ficción" necesaria de igualdad que es constitutiva de la institución ${ }^{110}$, o de "proveer" de la mayor confianza posible al inversionista ${ }^{111}$ basada en el respeto a un principio básico de esta clase de interacciones o, incluso, de un estado psicológico creado por dichas expectativas ${ }^{112}$.

Así las cosas, esta parte de la doctrina - que incluye a quienes fundamentan el injusto penal desde deberes positivos y negativos - aceptaría como único modelo de mercado de valores

\footnotetext{
${ }^{108}$ PIÑA ROCHEFORT, “Algunos problemas del delito”, cit. nota n 11, pp. 121 y ss.

${ }^{109}$ Véase de manera ejemplificadora PIÑA ROCHEFORT, “Algunos problemas del delito", cit. nota n ${ }^{\circ} 11, \mathrm{p}$. 118.

${ }^{110}$ PIÑA ROCHEFORT, “Algunos problemas del delito”, cit. nota n 11, p. 122.

${ }^{111}$ Ver VÁSQUEZ PALMA, cit. nota ${ }^{\circ} 11$, p. 246.

112 MONTENEGRO, Tutela penal de la Información privilegiada, cit. nota ${ }^{\circ} 11$, p. 42 y s; CANALES, cit. nota $\mathrm{n}^{\circ} 11$, p. 1 y 20. Estos autores, que han optado por una idea psicologicista de la Confianza, optan por aclarar que se trata de las confianzas individuales de un gran número de inversionistas. Si bien esta orientación no es desarrollada por dichos autores, es posible constatar que para esta concepción, la confianza como cualidad necesaria para participar en el sistema, es un atributo personal de cada individuo y, como tal, protegido individualmente. Queda, sin embargo, abierta la interrogante sobre la relevancia penal de dicha interpretación de la "dañosidad social".
} 
GARCÍA PALOMINOS, Gonzalo. "La idealización y la administrativización de la punibilidad del uso de Información Privilegiada. Un análisis de los discursos penales en la doctrina chilena”.

el neoinstitucional y sus consecuencias. La divergencia surge, entonces, ya no sólo en el fin de protección de la norma, sino en definir si al derecho penal le corresponde reforzar un "ideal" normativo (creado por la misma norma de conducta), pero inexistente en la institución o, por el contrario, le corresponde proteger sistemas organizados y existentes que garanticen alguna expectativa, como el igual acceso a información relevante. Pareciera ser, sin embargos, que los discursos de la literatura mayoritaria, ejemplificada aquí por la opinión de Rosas y Piña Rochefort, pero también utilizada originalmente por el legislador ${ }^{113}$ y la doctrina mayoritaria, optan derechamente por la primera y homologan la función del derecho penal con la del derecho económico (prepenal) en el sentido de "crear" o "reforzar" normativamente expectativas que permitan el desarrollo de negocios en dicho sistema, revirtiendo ciertos niveles de asimetría connaturales en las interacciones humanas o derechamente neutros, pero que desincentivan su participación en un mercado altamente dependiente de la información ${ }^{114}$.

\subsubsection{Pérdida de la capacidad de funcionamiento del mercado de valores.}

Esta tesis idealista común a las distintas propuestas, vincula adicionalmente, como ya se ha visto, la igualdad de acceso a la información relevante con la pérdida de confianza en la institución y directamente con la pérdida de capacidad de funcionamiento del mercado de valores. La lesividad como disfuncionalidad consistiría en la afectación de dicha funcionalidad provocada por la ejecución de conductas vulneradoras de la expectativa de igualdad o asimetría de la información lo que, en concreto, provocaría una consecuente alza del valor del capital para las compañías y una menor liquidez por la menor confluencia de inversionistas $^{115}$. Con ello, adicionalmente, se imposibilitaría el cumplimiento de las funciones de distribución (Allokationsfunktion), operacionales e institucionales ${ }^{116}$. Se trata todas funciones propias y exclusivas de los mercados organizados y de valores en sentido estricto, aun cuando discursivamente son ampliadas sin distinción a todo tipo de mercados.

En definitiva, la utilización de un discurso legitimante que, a su vez, pudiera servir a la reconstrucción valorativa del injusto penal sólo es aceptado en sus formas externas, pero no substancialmente. Se trata, por lo mismo, de una mera desobediencia (o trampa a las reglas del juego) como fuente de disfuncionalidad macroinstitucional (no disfuncionalidad para sistemas específicos garantizadores de expectativas). Hasta ahora, la literatura sólo ha recurrido a una insuficiente y poco acreditado argumento de "necesidad" de pena (no existe ningún medio igual o menos gravoso para proteger el bien jurídico) para justificar la intervención penal en este ámbito ${ }^{117}$, Sin embargo, no solucionan el problema ni de la legitimación ni de la reconstrucción valorativa.

\footnotetext{
${ }^{113}$ Informe Técnico del Ministro de Hacienda en 1981, ver en: RIED UNDURRAGA, "Fundamentos de la Prohibición", cit. nota ${ }^{\circ} 11$, p. 446.

${ }_{114}$ Así, véase, por ejemplo, CANALES, cit. nota $\mathrm{n}^{\circ}$ 11, p. 20.

115 SALAH, Responsabilidad por uso de Información Privilegiada, cit. nota ${ }^{\circ}$ 11, p. 56 y s; p. 69.

116 Ver ASSMANN, Heinz-Dieter, “§ 1 WpHG”, en: ASSMANN, Heinz-Dieter; SCHNEIDER, Uwe (Eds.), Wertpapierhandelsgesetz: $3^{\text {a }}$ edición, Köln, 2003, §1, número al margen 23 y ss.; en la literatura chilena SALAH, Responsabilidad por uso de Información Privilegiada, cit. nota ${ }^{\circ} 11$, p. 56 y s. y p. 69.

${ }^{117}$ PIÑA ROCHEFORT, “Algunos problemas del delito”, cit. nota ${ }^{\circ} 11$, pp. 122 y ss.
} 
Polít. crim. Vol. 10, № 19 (Julio 2015), Art. 5, pp. 119-158.

[http://www.politicacriminal.cl/Vol_10/n_19/Vol10N19A5.pdf]

\section{Resultado 2: ¿Acumulación lesiva y mera desobediencia como constitutiva del injusto penal en el uso de información privilegiada?: el abandono de la metodología clásica.}

Superada la idea en la doctrina de que respecto de los bienes jurídicos colectivos eran perfectamente aplicables las teorías de la peligrosidad elaboradas para bienes jurídicos individuales fácilmente lesionables por medio de una conducta individual (delito basado en el paradigma de la lesión patrimonial) - tales como las llamadas teoría del peligro general ${ }^{118} \mathrm{o} \mathrm{la}$ teoría de la presunción ${ }^{119}$ - la dogmática penal del peligro se ha abocado a determinar las "verdaderas" relaciones lesivas entre conductas individuales y bienes jurídicos colectivos ${ }^{120}$. La principal contribución de dichas investigaciones - y que dicen relación con la necesidad revitalizar la metodología propuesta por la teoría de la lesividad social - es la desmitificación del objeto de protección penal y la relación de dañosidad que, hasta ahora, aportaba sólo discursos que permitían una configuraban "ficticia" de injustos penales ${ }^{121}$. Este análisis persigue precisamente desenmascarar dichos discursos penales espurios, de manera de permitir legitimar razonablemente la intervención penal, pero además posibilitar una reconstrucción de injusto penal adecuada y legítima.

La literatura sobre los delitos económicos y, en particular del uso de información privilegiada, no ha sido la excepción a la necesidad de enfrentar el problema. En efecto, junto con la idealización de la lesividad social, se han identificado en este análisis una tendencia de la doctrina a vincular al bien jurídico penal con macroestructuras institucionales - como el mercado de valores o la confianza institucionalizada en el mismo -, tendencia que se ve obligada - en caso de aceptar, al menor en la forma este discurso legitimador - a recurrir a criterios acumulativos para explicar la relación de lesividad. Tanto en los fundamentos expresados por el legislador en las distintas fases de desarrollo de

\footnotetext{
${ }^{118}$ KINDHÄUSER, Urs, (Gefährdung als Straftat: rechtstheoretische Untersuchung zur Dogmatik der abstrakten und konkreten Gefährdungsdelikte, Frankfurt a. M.: Ed. Vittorio Klostermann, 1989, pp. 229 y ss.; pp. 238 y ss.) nombra a esa teoría como teoría de "la relevancia lesiva general", mientras que GRAUL, Eva (Abstrakte Gefährdungsdelikte und Präsumtionen im Strafrecht, Berlin: Düncker \& Humblot, Bd. 69, 1991, p. 144 y s.) nombra a estos delitos como "peligro- peligrosidad - teoría de la motivación" (Gefahr-/GefährlichkeitsMotivtheorie).

${ }^{119}$ KINDHÄUSER, (Gefährdung als Straftat, cit. nota n ${ }^{\circ} 118$, pp. 229 y ss., pp. 238 y ss.) bautiza a esta teoría como "teoría de relevancia lesiva abstracta (Die abstrakte Verletzungsrelevanz), y GRAUL (Abstrakte Gefährdungsdelikte, cit. nota n¹18, pp. 144 y s.) como teoría de la presunción ("Die Theorie der abstrakten Gefährlichkeit/Gefahr; Gefahr-/Gefährlichkeits-Präsumtionstheorie").

120 Ampliamente en las obras de HEFENDEHL, Kollektive Rechtsgüter, cit. nota $\mathrm{n}^{\circ} 8$ y ANASTASOPOULOU, Ioanna, Deliktstypen zum Schutz kollektiver Rechtsgüter. München: C.H. Beck, 2005.

${ }^{121}$ SCHÜNEMANN, Bernd, "Moderne Tendenzen in der Dogmatik der Fahrlässigkeit", JA, 1975, S. 792 y ss; EL MISMO, "Das Rechtsgüterschutzprinzip", cit. nota n ${ }^{\circ}$ 2, p. 133 y ss; una opinión crítica HERZOG, Felix, Gesellschaftiche Unsicherheit und strafrechtliche Daseinsvorsorge: Studien zur Vorverlegung des Strafrechtsschutzes in den Gefährdungsbereich, Heidelberg: R. v. Decker, 1991, pp. 33 y ss.; MARXSEN, Dorothea, Strafbarkeitseinschränkung bei abstrakten Gefährdungsdelikten, Münster, Hamburg: Juristische Schriftenreihen, Bd. 18, 1991. pp. 58 y ss; SCHMIDT, Jürgen, Untersuchung zur Dogmatik und zum Abstraktionsgrad abstrakter Gefährdungsdelikte, Bd. 24. Marburg: N.G. Erwert Verlag Marburg, 1999, pp. 66 y ss; WOHLERS, Wolfgang, Deliktstypen des Präventionsstrafrechts - zur Dogmatik „,moderner" Gefährdungsdelikte, Basel: Duncker \& Humblot, 2000, pp. 299 y ss; HEFENDEHL, Kollektive Rechtsgüter, cit. nota n ${ }^{\circ}$ 8, pp. 175 y ss; ANASTASOPOULOU, Deliktstypen zum Schutz, cit. nota n ${ }^{\circ}$ 120, pp. 146 y ss.
} 
GARCÍA PALOMINOS, Gonzalo. "La idealización y la administrativización de la punibilidad del uso de Información Privilegiada. Un análisis de los discursos penales en la doctrina chilena”.

la discusión como en la literatura nacional e internacional, la relación de lesividad entre la conducta individual y el bien jurídico tendrían dicho carácter ${ }^{122}$.

En efecto, como ya se ha destacado anteriormente, los discursos de la literatura penal relativos a estos delitos económicos se han ido construyendo sobre la base de la protección del adecuado funcionamiento del mercado de valores y, en especial, porque determinadas prácticas como la manipulación de precios o el uso de información privilegiada constituyen prácticas que reducen la confianza en la equidad del sistema, factor que inhibe su profundización y masificación ${ }^{123}$. La idea de la dependencia del funcionamiento de la institución de los niveles de confianza, entonces, es considerada como un elemento esencial $^{124}$, cuya configuración es necesaria de proteger frente al conjunto de conductas que, acumuladas, pueden llegar a ser lesivas al mismo ${ }^{125}$. Respecto a dicho objeto de protección se ha tendido a considerar la lesividad de manera "idealizada" ("el daño estaría manifestado por una vulneración de los principios de igualdad y trasparencia que persiguen este tipo de disposiciones" 126 o, como señala la Corte Suprema, la lesión al derecho de los distintos operadores a intervenir en el mercado teniendo acceso igualitario a la información $(\ldots)^{\prime \prime 27}$ ) o, desde un punto de vista causal, como acumulativa:

“(...) en la medida que se conocen casos de personas que teniendo acceso a información relevante - sea en virtud de su posición en un ente emisor, de su participación en el capital de éste o de su profesión, cargo u oficio - se aprovecha de esta (...) obteniendo con ello injustamente beneficios o evitando pérdidas, la consecuencia es que los ahorrantes vayan perdiendo confianza en el mercado de valores como alternativa al sistema bancario. En tales circunstancias llegan menos inversores al mercado de valores y otros lo abandonan, viéndose mermado un factor clave para su optimo funcionamiento.",128

En el mismo sentido y utilizando la idea de dañosidad acumulativa, explica Montenegro la lesividad señalando que si bien es cierto que el abuso de información privilegiada por parte de un solo sujeto puede ser del todo inepto para dañar de manera considerable la confianza de los demás inversores en el mercado de valores, sumados unos con otros, son capaces de atacar la pureza del mercado y con mayor razón dañar la confianza en el mismo. De ahí

\footnotetext{
${ }^{122}$ Un completo estudio sobre la acumulación, véase en HEFENDEHL, Kollektive Rechtsgüter, cit. nota ${ }^{\circ} 8$.

${ }^{123}$ Véase la intervención del Sr. Ministro de Hacienda Alejandro Foxley, en Actas de Formación de la Ley Nr. 19.301 de 1994, en: Sesión del Senado 15 Octubre de 1993, Legislatura 327a , Extraordinaria, pp. 20 y 21; Sesión 22a, en 11 de enero de 1994, Legislatura 327 a Extraordinaria, p. 14; véase también intervención de Claudio Huepe, (Diputado informante) en Acta Sesión 8 de Junio de 1993, en: RIED UNDURRAGA, "Fundamentos de la Prohibición", cit. nota n 11, pp. 439, 449 y ss.

${ }^{124}$ CANALES, cit. nota $\mathrm{n}^{\circ} 11, \mathrm{p} .2$.

${ }^{125}$ ROSAS, "El Delito de Abuso", cit. nota n 11, p. 11; en el mismo sentido ONFRAY, "Ilícitos contra la información", cit. nota ${ }^{\circ}$ 11, p. 79 y ss.; MONTENEGRO, Tutela penal de la Información privilegiada, cit. nota $\mathrm{n}^{\circ} 11$, p. 42.

${ }^{126}$ Véase SALAH, Responsabilidad por uso de Información Privilegiada, cit. nota n ${ }^{\circ}$ 11, p. 201.

${ }^{127}$ Véase Exc. Corte Suprema, causa Rol Nr. 3.364 de 2006, considerando Nr. 14; ver análisis en: GUZMÁN ANRIQUE, Información Privilegiada, cit. nota $\mathrm{n}^{\circ}$ 11, p. 78.

${ }^{128}$ ROSAS, cit. nota ${ }^{\circ}{ }^{11}$, p. 11; en el mismo sentido ONFRAY, "Ilícitos contra la información", cit. nota ${ }^{\circ}$ 11, pp. 79 y ss.; MONTENEGRO, Tutela penal de la Información privilegiada, cit. nota n 11, p. 42.
} 
Polít. crim. Vol. 10, № 19 (Julio 2015), Art. 5, pp. 119-158.

[http://www.politicacriminal.cl/Vol_10/n_19/Vol10N19A5.pdf]

que, como reacción a lo anterior, se dañaría también el adecuado funcionamiento del mercado de valores ${ }^{129}$.

La identificación y verdadera configuración de los bienes jurídicos colectivos, en especial, los institucionales, ha dado paso a nuevas explicaciones sobre la relación de dañosidad. La acumulación, como idea explicativa de dicha relación lesiva así como criterio legitimador, ha ido llenando los vacíos argumentales y ficciones teóricas tanto a nivel legislativo como dogmático. En efecto, ya Fritz Loos (1974) ${ }^{130}$ para el delito del cohecho o Lothar Kuhlen (1986 - 1993) ${ }^{131}$ para el delito de contaminación de aguas fueron pioneros en desmitificar la configuración de los bienes jurídico (por ej. La negación de la pureza de la función pública) y desidealizar la relación de lesividad (más allá del peligro), explicándola con la idea acumulativa. Actualmente autores como Hefendehl hacen lo mismo en relación a amplios grupos de delitos, en especial, aquellos que protegen la "confianza" ${ }^{132}$. En general, para esta tendencia, a diferencia de los bienes jurídicos individuales que pueden ser dañados por una conducta individual, para bienes jurídicos colectivos dicha causalidad no es posible ${ }^{133}$. Sin embargo, como señala Hefendehl, como la relación de capacidad lesiva entre la conducta y el bien jurídico es necesaria (Eignungszusammenhang) incluso en los delitos de peligro abstracto, se hace indispensable intensificar la búsqueda de dicha relación e, incluso, forzarla. Por lo mismo, propone que frente a la falta de una "real" capacidad lesiva sea necesario exigir - al menos en el plano de la criminalización (legislador) - una relación acumulativa ${ }^{134}$, lo que implicaría, en todo caso, que en el plano de la tipicidad el desvalor del acto pasa a primer plano, en perjuicio del desvalor de resultado ${ }^{135}$. Con esto, este autor no hace otra cosa sino que renunciar a la reconstrucción de injusto penal desde la lesividad social, dejando sin solución la necesaria cualificación del injusto.

Precisamente, los injustos penales basados en criminalizaciones por la idea acumulativa de lesividad, como ha sido la idea propuesta por parte de la literatura chilena en relación tanto a la manipulación de precios como al uso de información privilegiada, no obstante constituir un avance - frente a la idealización o espiritualización de los bienes jurídicos colectivos , presentan un doble problema, según sea la interpretación de la idea acumulativa: a) Si la idea de dañosidad social acumulativa es trasladada al plano típico, la falta de lesividad de la conducta individual se ve obligada a configurar un injusto personal basado en la conducta de otro u otros

\footnotetext{
${ }^{129}$ MONTENEGRO, Tutela penal de la Información privilegiada, cit. nota ${ }^{\circ} 11$, pp. 42 y ss.

${ }^{130}$ Según LOOS, Fritz, (“Zum „Rechtsgut" der Bestechungsdelikte”, en: STRATENWERTH, Günter et. al. (Eds.), Festschrift für Hanz Welzel, Berlin, New York: De Gruyter, 1974, pp. 879 - 891 y ss.) la conducta individual de cohecho sería incapaz, con excepción de casos muy extremos, de dañar las condiciones de funcionamiento del aparato estatal o el funcionamiento de la administración pública. En cambio, una cantidad importante de dichas conductas podrían efectivamente ocasionar dicho daño, principalmente por su significación expresiva.

${ }^{131}$ Ver KUHLEN, Lothar, "Der Handlungserfolg der strafbaren Gewässerverunreinigung [§ 324 StGB] ”, GA, 133. Jg. Heidelberg, 1986, pp. 389 y ss.; EL MISMO, "Umweltstrafrecht - auf der Suche nach neuen Dogmatik", ZStW, Bd. 105, 1993, pp. 697 y ss.

${ }^{132}$ HEFENDEHL, Kollektive Rechtsgüter, cit. nota ${ }^{\circ}$ 8, pp. 182 y ss; EL MISMO, Die Rechtsgutstheorie, cit. nota $\mathrm{n}^{\circ} 8$, pp. 130 y ss.

${ }^{133}$ HEFENDEHL, Kollektive Rechtsgüter, cit. nota n 8, p. 36, p. 191.

${ }^{134}$ HEFENDEHL, Kollektive Rechtsgüter, cit. nota ${ }^{\circ} 8$, pp. 182 y ss.

${ }^{135}$ HEFENDEHL, Die Rechtsgutstheorie, cit. nota $\mathrm{n}^{\circ}$ 8, pp. 130.
} 
GARCÍA PALOMINOS, Gonzalo. "La idealización y la administrativización de la punibilidad del uso de Información Privilegiada. Un análisis de los discursos penales en la doctrina chilena".

(ex iniuria tertii) ${ }^{136}$, lesionando con ello el principio de culpabilidad ${ }^{137}$; b) para quienes, como Hefendehl, sostienen que se trata de un criterio de legitimación basado en la dañosidad social de la conducta con relevancia sólo a nivel de criminalización (nivel legislativo) ${ }^{138}$, excluyéndola de las exigencias a nivel típico y de la configuración del injusto - evitando la vulneración del principio de culpabilidad - se produce el problema que los injustos penales o siguen configurándose sobre la base de ficciones, renunciando con ello abiertamente a la calificación de los mismos o se renuncia a contar con aspectos objetivos que permiten diferenciar - a nivel institucional - de entre las vulneraciones normativas disfuncionales aquella que tenga relevancia penal de aquellas que no la tienen. En otras palabras, se corre el riesgo de sancionar meras conductas bagatelares ${ }^{139}$ o meras desobediencias ${ }^{140}$ que pueden ser relevantes - por su disfuncionalidad - para el derecho comercial o administrativo sancionador, pero insuficientes para concretar un injusto penal "cualificado".

Lo anterior es especialmente relevante en ordenamientos jurídicos como el chileno que no hacen diferencias relevantes entre el injusto administrativo y el penal de uso de información privilegiada ni incluyen elementos objetivos o subjetivos especiales que permitan cualificar la mera vulneración normativa en el ámbito penal.

\section{Conclusión.}

El presente trabajo ha propuesto una discusión en lo que podría llamarse la "periferia" entre el derecho administrativo sancionador y el derecho penal y precisamente en lo que Stuart Green llama híbridos civiles/penales ${ }^{141}$ en que las decisiones de perseguir penalmente o civilmente (refiriéndose al derecho administrativo sancionador) queda a discreción del aplicador del derecho (fiscal) ${ }^{142}$. Lo anterior, no constituiría problema alguno si, del análisis desarrollado, fluyera naturalmente un contenido material del ilícito indiscutido y esta decisión estuviera fundada solamente en la accesoriedad del derecho penal ${ }^{143}$. Sin embargo, aquello no ocurre en la criminalización del uso de información privilegiada y, peor aún, este delito en su contenido material forma parte de aquello que el autor antes citado denomina un "delito trivial" (malum

\footnotetext{
${ }^{136}$ Ver DAXENBERGER, Matthias, Kumulationseffekte. Grenzen der Erfolgszurechnung im Umweltstrafrecht, Baden-Baden: Nomos, 1997, p. 66.

${ }^{137}$ PAPAMOSCHOU, Marscha; BUNG, Jochen, “\$ 265 StGB: Eine legislative Entgleisung”, en: Institut für Kriminalwissenschaften Frankfurt a. M. (Hrsg.), Irrwege der Strafgesetzgebung, Frankfurt a. M. 1999, pp. 257.

${ }^{138}$ HEFENDEHL, Kollektive Rechtsgüter, cit. nota $\mathrm{n}^{\circ}$ 8, p. 188.

139 Ver ROGALL, Klaus, "Gegenwartsprobleme des Umweltstrafrechts", en: VVAA, Festschrift der Rechtswissenschaftlichen Fakultät zur 600-Jahr-Feier der Universität zu Köln, Köln: Universität zu Köln 1988, p. 520; DAXENBERGER, Kumulationseffekte, cit. nota ${ }^{\circ} 136$, p. 65.

${ }^{140}$ Sobre la problemática y planteando algunas soluciones KUHLEN, "Der Handlungserfolg", cit. nota $\mathrm{n}^{\circ} 131$, pp. 407 y ss.; EL MISMO, cit. nota $\mathrm{n}^{\circ} 131$ (1993), pp. 697 y ss.; WOHLERS, Deliktstypen des Präventionsstrafrechts, cit. nota $\mathrm{n}^{\circ}$ 121, pp. 324 y ss.; HEFENDEHL, Kollektive Rechtsgüter, cit. nota $\mathrm{n}^{\circ} 8$, pp. 187 y ss.; EL MISMO, Die Rechtsgutstheorie, cit. nota $\mathrm{n}^{\circ}$ 8, p. 131; ver ANASTASOPOULOU, Deliktstypen zum Schutz, cit. nota ${ }^{\circ} 120$, pp.185 y ss.

${ }^{141}$ GREEN, Mentir, hacer trampas y apropiarse, cit. nota ${ }^{\circ} 17$, p. 54.

${ }^{142}$ Esto sucede en Chile con el uso de información privilegiada, según lo dispone el art. 55 y los art. 165 y ss. en relación con el art. $60 \mathrm{LMV}$.

${ }^{143}$ Una idea diferente se puede colegir, aunque con dudas, en PIÑA ROCHEFORT, “Algunos problemas del delito", cit. nota $\mathrm{n}^{\circ} 11$, p. 122.
} 
Polít. crim. Vol. 10, № 19 (Julio 2015), Art. 5, pp. 119-158.

[http://www.politicacriminal.cl/Vol_10/n_19/Vol10N19A5.pdf]

prohibitum o es ilícito porque está prohibido) que, a menudo resulta insuficiente para justificar una sanción penal, precisamente porque no se contempla universalmente como merecedor de pena $^{144}$. El problema no sólo es de importancia para la legitimación, sino para la aplicación del derecho: ¿cuál de todas las posibles conductas abarcadas por el tipo penal, realmente configuran el injusto de aquel delito?

La literatura mayoritaria acá analizada, sin embargo, ha buscado justificar la criminalización y, con ello, reconstruir el injusto (ilícito) del delito de uso y difusión de información privilegiada utilizando discursivamente, aunque no exclusivamente, la metodología de la lesividad social de las conductas. Para ello ha optado, siguiendo tesis económicas neoinstitucionales, por orientar dicha reconstrucción desde la macro-configuración de la institución mercado de valores, es decir, explicar la lesividad de la conducta según su capacidad de afectar el funcionamiento general de dicho mercado o la fe o confianza pública en la igualdad de oportunidades en el acceso a la información. Dicha opción fracasa rotundamente en la búsqueda de la respuesta.

Por un lado fracasa, porque dicho discurso idealizado y generalizante alcanza injustificadamente, incluso, a mercados no organizados ni formalizados, incapaces de garantizar mínimamente expectativas como la del igual acceso a la información o del funcionamiento institucional. En segundo lugar fracasa porque sólo es capaz de justificar las normas de conductas que limitan administrativamente la libertad económica y prohíben beneficiarse de ventajas informativas en mercados regulados y organizados, no así, sin embargo, por justificar la criminalización (merecimiento y necesidad de pena) ni explicar el contenido del injusto penal "cualificado". En efecto, todas las instituciones económicas "organizadas" son configuradas normativamente como sistemas de incentivo y, por lo mismo, regulan las conductas de los participantes en el mismo de manera de posibilitar los modos de interacción que se pretenden incentivar - según los fines que se pretendan perseguir - y según el esquema preconfigurado de interacción del modelo ideal de eficiencia elegido. Dicho modelo ideal se configura sobre la base de ofrecer a quienes interactúan en sus sistemas posibilidades de interacción que de otra forma no existirían, ya que reducen la incertidumbre e inseguridad que, de otra manera, o no permitirían la interacción o serían directamente asumidas por uno de los intervinientes. Frente a la posibilidad de entender la configuración del mercado de valores desde una perspectiva neoclásica (orientado a sistemas garantizadores de expectativas informativas) o neoinstitucional (coordinación y eliminación de conductas disfuncionales), sin embargo, los discursos penales han optado exclusivamente por la segunda. Con ello, se ha optado por una perspectiva exclusivamente normativa que sólo es capaz de explicar la justificación de la criminalización y la desvaloración de la conducta recurriendo a efectos macroinstitucionales producidos por el incumplimiento de las reglas de funcionamiento (malum prohibitum), según un supuesto efecto acumulativo ${ }^{145}$.

Si bien, desde una dimensión formal, parte del problema ya ha sido solucionado en tanto el legislador legitimado democráticamente ha seleccionado el "uso (abuso) y divulgación de

\footnotetext{
${ }^{144}$ GREEN, Mentir, hacer trampas y apropiarse, cit. nota $\mathrm{n}^{\circ} 17$, pp. 54 y ss.

${ }^{145}$ Sobre este tema ver GUZMÁN ANRIQUE, Información Privilegiada, cit. nota $\mathrm{n}^{\circ} 11$, pp. 10 y ss.; RIED UNDURRAGA, "Fundamentos de la Prohibición", cit. nota n 11, pp. 115, 439, 448 y ss.
} 
GARCÍA PALOMINOS, Gonzalo. "La idealización y la administrativización de la punibilidad del uso de Información Privilegiada. Un análisis de los discursos penales en la doctrina chilena”.

información privilegiada" de entre muchas otras conductas disfuncionales para el mercado de valores, sin embargo, resulta insuficiente si de lo que se trata es reconstruir un injusto que, al igual que para el derecho penal clásico, va a fundamentar la culpabilidad penal. La opción por reconstruir la estructura típica desde la perspectiva que dan las teorías neoinstitucionales (macroinstitucionales) y la aceptación de la "acumulación" lesiva como un "equivalente material" frente a la falta de potencialidad lesiva de la conducta individual, atentan contra la búsqueda de dicho injusto (penal) cualificado.

Por ahora, y no obstante la búsqueda quede abierta, sin embargo, queda patente un nuevo camino inexplorado por la literatura penal: la búsqueda de explicaciones desde la perspectiva neoclásica (microinstitucional - homo economicus) y el acercamiento a la reconstrucción lesiva utilizando equivalentes "funcionales" más coherentes con la naturaleza sistémica de las instituciones económicas. 
Polít. crim. Vol. 10, № 19 (Julio 2015), Art. 5, pp. 119-158.

[http://www.politicacriminal.cl/Vol_10/n_19/Vol10N19A5.pdf]

\section{BIBLIOGRAFÍA}

ABANTO, Manuel, “Acerca de la teoría de bienes jurídicos”, Revista Penal, № 18 (2006), Madrid, pp. 3 y ss.

ALCALDE RODRÍGUEZ, Enrique, "Uso de Información Privilegiada: Algunas consideraciones sobre el sentido y alcance de la prohibición en relación con su sujeto, objeto y sanción", Revista Chilena de Derecho, vol. 27, N 1 (2000), pp. 11 y ss.

ANASTASOPOULOU, Ioanna, Deliktstypen zum Schutz kollektiver Rechtsgüter. München 2005 .

ASSMANN, Heinz-Dieter, "§ 1 WpHG", en: ASSMANN, Heinz-Dieter; SCHNEIDER, Uwe (Eds.), § Wertpapierhandelsgesetz: $3^{\text {a }}$ edición, Köln, 2003, §1, número al margen 23 y ss.

BAJO FERNÁNDEZ, Miguel, "Uso de información privilegiada", en: El nuevo Código penal: presupuestos y fundamentos, Libro Homenaje al Prof. Dr. D. Ángel Torío López, Granada: Comares, 1999.

BARROS, Enrique, Tratado de Responsabilidad Extracontractual, Santiago: Ed. Jurídica de Chile, 2006.

BASCUÑÁN RODRIGUEZ, Antonio, "La regulación de la información Privilegiada en el mercado de Valores después de la Ley 20.382”, en: VVAA, Gobiernos Corporativos. Aspectos especiales de las Reformas a su regulación, Universidad Adolfo Ibáñez, Santiago: Editorial AbeledoPerrot, 2011, pp. 87-138.

BÖSE, Martin, "Grundrechte und Strafrecht als Zwangsrecht”, en: HEFENDEHL, Roland u. a. (Ed.), Die Rechtsgutstheorie, Baden-Baden: Nomos Verlagsgesellschaft, 2003, p. 89 y ss.

BUCK - HEEB, Petra, Kapitalmarktrecht, „§ 1 II“, Heidelberg: Editorial C. F. Müller, 2008 .

BUSTOS, Juan; HORMAZABAL, Hernán, Lecciones de Derecho Penal I, Madrid: Trotta, 1999.

CANALES, Patricia, Información Privilegiada en el Mercado de Valores, Serie de Estudios de Anticipación/CEA, Biblioteca del Congreso Nacional de Chile, Año II, $\mathrm{N}^{\circ} 18$, Mayo de 2003.

CICERÓN, Tulio, Obras Completas, T. IV, Capítulo 3 de los Oficios, Libro XII, (Traducción de Valbuena, Manuel); [http://www.bibliojuridica.org/libros/libro.htm?l=774].

DAXENBERGER, Matthias, Kumulationseffekte. Grenzen der Erfolgszurechnung im Umweltstrafrecht, Baden-Baden: Nomos, 1997.

FAMA, Eugene, "Efficient Capital Markets: A Review of Theory and Empirical Work", Journal of Finance, Vol. 25, (2), 1970, pp. 383-417.

FEIJOO SÁNCHEZ, Bernardo, Cuestiones actuales de Derecho Penal, Montevideo, Buenos Aires: Ed. B de f, 2009.

FILIPIUK, Bogna, Transparenz der Risikoberichterstattung, Wiesbaden: Springer Gabler Ed., 2008.

FLEISCHER, Holger, "Grundfragen der ökonomischen Theorie im Gesellschafts- und Kapitalmarktrecht", Zeitschrift für Unternehmens- und Gesellschaftsrecht, Cuaderno 1, 2001, pp. 1 y ss. 
GARCÍA PALOMINOS, Gonzalo. "La idealización y la administrativización de la punibilidad del uso de Información Privilegiada. Un análisis de los discursos penales en la doctrina chilena".

FRISCH, Wolfgang, "Geglückte und folgenlose Strafrechtsdogmatik”, en: ESER, Albin; HASSEMER, Winfried; BURKHARDT, Björnd, Die deutsche Strafrechtswissenschaft vor der Jahrtausendwende, München: H. Beck, 2000, pp. 159 y ss.

"Rechtsgut, Recht, Deliktsstruktur und Zurechnung im Rahmen der Legitimation staatlichen Strafens", en: HEFENDEHL, Roland (Ed.), Die Rechtsgutstheorie, Baden Baden: Nomos Verlagsgesellschaft, 2003, pp. 215 y ss.

GARCÍA PALOMINOS, Gonzalo, "Modelo de protección en normas administrativas y penales que regulan el abuso de Información Privilegiada en la legislación chilena", Polit. crim., Vol. 8, $\quad \mathrm{N}^{\mathrm{o}} 15 \quad$ (Julio 2013), pp. 23-63. [http://www.politicacriminal.cl/Vol 08/n 15/Vol8N15A2.pdf]

, "Del paradigma de la dañosidad social centrado en la infracción normativa al paradigma metodológico centrado en la norma de sanción: un falso dilema", en: BLACNO, R.; IRURETA, P. IRURETA (Eds.) Justicia, Derecho y Sociedad, Libro en Memoria de Maximiliano Prado D., Santiago: Ediciones Universidad Alberto Hurtado, 2014, pp. 143 y ss.

GARRIDO MONTT, Mario, Derecho Penal, Parte General, Tomo I, Santiago de Chile: Editorial Jurídica de Chile, 2003.

GASPAR, José Antonio; ARAYA, Fernando, "Uso de Información Privilegiada: Superintendencia de Valores y Seguros, 14 de abril de 2011, Resolución Exenta N ${ }^{\circ}$ 229”, Revista Chilena de Derecho Privado, No 17 (2011), pp. 277-305.

GEERDS, Detlev, Wirtschaftsstrafrecht und Vermögensschutz, Lübeck: Max SchmidtRömhild, 1990.

GIL, Javier Alfonso, "Instituciones económicas: contornos de triada básica", Revista Economistas, Nr. 73, 1997, pp. 128 y ss.

GRAUL, Eva, Abstrakte Gefährdungsdelikte und Präsumtionen im Strafrecht, Berlin: Düncker \& Humblot GmbH, 1991, p. 144 y s.

GREEN, Stuart, Mentir, hacer trampas y apropiarse de lo ajeno, Madrid, Barcelona, Buenos Aires: Marcial Pons, 2013.

GROSSMAN, Sanford J.; STIGLITZ, Joseph, "Information and Competitive Price Systems", American Economic Review, Vol. 66, No 2 (1976), pp. 246 y ss.

GRUNEWALD, Barbara; SCHLITT, Michael, Einführung in das Kapitalmarktrecht, München: C. H. Beck Verlag, 2007.

GUZMÁN ANRIQUE, Francisco, Información Privilegiada en el Mercado de Valores, Santiago: Lexis Nexis, 2007.

HAGEMANN, Michael H., Grauer Kapitalmarkt und Strafrecht, Osnabrück: V\&R unipress GmbH, 2005.

HASSEMER, Winfried, Theorie und Soziologie des Verbrechens, Frankfurt a. M.: Athenäum Fischer Taschenbuch Verlag, 1973. "Symbolisches Strafrecht und Rechtsgutschutz", Neue Zeitschrift für Strafrecht, Heft 12. (1989), pp. 553 y ss.

HEFENDEHL, Roland, Kollektive Rechtsgüter im Strafrecht, Köln: Carl Heymanns Verlag KG, 2002. 
Polít. crim. Vol. 10, № 19 (Julio 2015), Art. 5, pp. 119-158.

[http://www.politicacriminal.cl/Vol_10/n_19/Vol10N19A5.pdf]

, “Das Rechtsgut als materieller Angelpunkt einer Strafnorm”, en: HEFENDEHL, Roland; VON HIRSCH, Andrew; WOHLERS, Wolfgang, Die Rechtsgutstheorie, Baden Baden: Nomos Verlagsgesellschaft, 2003, pp. 119 y ss.

HERZOG, Felix, Gesellschaftliche Unsicherheit und strafrechtliche Daseinsvorsorge: Studien zur Vorverlegung des Strafrechtsschutzes in den Gefährdungsbereich, Heidelberg: R. v. Decker, 1991

JANSEN, Dorothea, "Theoriekonzepte in der Analyse sozialer Netzwerke, Entstehung und Wirkungen, Funktionen und Gestaltung sozialer Einbettung", FÖV Discussion Papers 39, Speyer, 2007.

KASSEBAUM, Ulf Bernd (Diss.), Interpersonelles Vertrauen, Entwicklung eines Inventars zur Erfassung spezifischer Aspekte des Konstrukts, Hamburg: Universität Hamburg, 2004.

KORIATH, Heinz, "Zum Streit um den Begriff des Rechtsguts", GA, 146. Jg. Heidelberg 1999 , pp. 561 y ss.

KRÜGER, Matthias, Die Entmaterialisierungstendenz bei Rechtsgutsbegriff, Bd. 35, Berlin: Duncker\&Humblot, 2000.

KINDHÄUSER, Urs, Gefährdung als Straftat: rechtstheoretische Untersuchung zur Dogmatik der abstrakten und konkreten Gefährdungsdelikte, Frankfurt a. M.: Ed. Vittorio Klostermann, 1989.

KUHLEN, Lothar, "Der Handlungserfolg der strafbaren Gewässerverunreinigung [§ 324 StGB]",. GA, 133. Jg. Heidelberg, 1986, pp. 389 y ss. ,"Umweltstrafrecht - auf der Suche nach neuen Dogmatik", ZStW, Bd. 105, 1993, pp. 697 y ss.

KÜMPEL, Siegfried, Bank- und Kapitalmarktrecht, Köln: Dr. Otto Schmidt Verlag, 2004.

LARS, Hild, Grenzen einer strafrechtlichen Regulierung des Kapitalmarktes, Frankfurt a. M (Alemania): Peter Lang Verlag, 2004.

LAGODNY, Otto, "Das materielle Strafrecht als Prüfstein der Verfassungsdogmatik", en: HEFENDEHL, Roland; VON HIRSCH, Andrew; WOHLERS, Wolfgang, Die Rechtsgutstheorie, Baden Baden: Nomos Verlagsgesellschaft, 2003, pp. 83 y ss.

LENENBACH, Markus, Kapitalmarkt- und Börsenrecht, RWS, Köln: Kommunikationsforum Verlag, 2010.

LIEBEL, Hermann, Täter - Opfer - Interaktion bei Kapitalanlagebetrug, Neuwied: Editorial Luchterhand, 2002.

LOOS, Fritz, “Zum „Rechtsgut“ der Bestechungsdelikte”, en: STRATENWERTH, Günter u. a. (Hrsg.), Festschrift für Hanz Welzel, Berlin: De Gruyter, 1974, pp. 879 y ss.

LONDOÑO, Fernando, "Ilícito de manipulación bursátil: fenómeno y lesividad. Aspectos de política sancionatoria", Polít. crim. Vol. 8, No 15 (Julio 2013), A3, p. 73 y ss. [http://www.politicacriminal.cl/Vol_08/n_15/Vol8N15A3.pdf]

LORENZINI, Fabiola, Futuros y Opciones, Conceptualización y Operatoria conforme a la Ley $N^{\circ}$ 18.045, Santiago: Ed. Lexis Nexis, 2006.

LUHMANN, Niklas, Vertrauen, 4. Stuttgart: Auflage, Lucius \& Lucius Verlag, 2009.

MARX, Michael, Zur Definition des Begriffs „Rechtsgut“. Prolegonema einer materialen Verbrechenslehre, Bd. 65. Köln (Alemania): Carl Heymanns Verlag, 1972.

MARXSEN, Dorothea, Strafbarkeitseinschränkung bei abstrakten Gefährdungsdelikten, Juristische Schriftenreihen, Bd. 18, Münster, Hamburg, 1991. 
GARCÍA PALOMINOS, Gonzalo. "La idealización y la administrativización de la punibilidad del uso de Información Privilegiada. Un análisis de los discursos penales en la doctrina chilena".

MERKT, Hanno; ROSSBACH, Oliver, "Zur Einführung: Kapitalmarktrecht", Juristische Schulung, Zeitschrift für Studium und Ausbildung, München, Frankfurt a. M.: C. H. Beck, 2003, pp. $217-224$.

MONTENEGRO, Alex (Tesis de grado), Tutela penal de la Información privilegiada en la Ley 18.045 sobre mercado de valores, Memoria para optar al grado de Licenciado en ciencias jurídicas y sociales, Pontificia Universidad Católica de Chile, Valparaíso, Chile, 2004.

NEE, Victor; INGRAM, Paul, "Embeddedness and Beyond: Institutions, Exchange, and Social Structure", en: BRINTON, M.; NEE, V. (Eds.), The New Institutionalism in Sociology, New York: Stanford University Press, 2002, pp. 19-45.

NORTH, Douglass, "Institutions", Journal of Economic Perspectives, vol. 5, N 1 (1991), p. $97-112$.

NOVOA, Raúl; NOVOA, Gabriela, Derecho de Mercado de Capitales, Santiago: Editorial Jurídica de Chile, 1995.

ONFRAY VIVANCO, Arturo, "Ilícitos contra la información en las transacciones de valores", Revista de Derecho Consejo de Defensa del Estado, N$^{\circ} 5$ (2001), pp. 73105.

PAPACHRISTOU, Marialena, Die strafrechtliche Behandlung von Börsen- und Marktpressmanipulationen, Frankfurt a. M.: Peter Lang Verlag, 2006.

PARK, Tido, “Kapitalmarktstrafrecht und Anlegerschutz", NStZ, Heft 7, 2007, pp. 369 ff.

PEETZ, Dietmar, Hedge-Fonds und Finanzmarktinstabilität, Universität Kassel

[https://kobra.bibliothek.uni-kassel.de/handle/urn:nbn:de:hebis:34-2007011916704].

PERRONE, Andrea, "Información en el mercado de valores y tutela del inversor", Polít. crim. Vol. 4, No 7 (Julio 2009), Art. 7, pp. 197-229 (1-33) p. 11. [http://www.politicacriminal.cl/Vol 04/n 07/Vol4N7A7.pdf].

PFEFFER U., Francisco, "Concepto de información privilegiada y deberes de conducta de quienes están en posesión de ella, a la luz de la jurisprudencia emanada de la Excma. Corte Suprema", Revista de Derecho Comercial, Universidad de Chile, No 1 (2010), pp. 155-181.

, "Nuevos deberes informativos y precisiones en torno al concepto de información privilegiada en el contexto de la ley que perfecciona el gobierno corporativo en empresas privadas", Revista Actualidad Jurídica, Universidad del Desarrollo, No 22 (2010), pp. 181-203;

, "Información Privilegiada. Nuevos criterios asentados en sentencias de la Excma. Corte Suprema.”, Revista Derecho Público Iberoamericano, Universidad del Desarrollo No 5 (2014), pp. 289-297.

PICOT, Arnold; DIETL, Helmut, "Informations(de-) regulierung am Kapitalmarkt aus institutionenökonomischer Sicht”, en: SCHENK, E; SCHMIDTCHEN, D. (Eds.), Jahrbuch für neue politische Ökonomie, Neue politische Ökonomie der Regulierung, Deregulierung und Privatisierung, Vol. 13, Tübingen: Mohr Siebeck, 1994, pp. 113136.

PIÑA ROCHEFORT, Juan Ignacio. "Algunos problemas del delito de uso de información privilegiada”, Cuadernos de Extensión Jurídica, Santiago, T. 19 (2009), pp. 113-135; 
Polít. crim. Vol. 10, № 19 (Julio 2015), Art. 5, pp. 119-158.

[http://www.politicacriminal.cl/Vol_10/n_19/Vol10N19A5.pdf]

PRADO PUGA, Arturo, “Acerca del concepto de Información Privilegiada en el mercado de valores chileno: Su alcance, contenido y Límites", Revista Chilena de Derecho, Vol. 30, $\mathrm{N}^{\circ} 2$ (2003), pp. 237-269.

RICHTER, Rudolf; FURUBOTN, Eirik, Neue Institutionenökonomik, $3^{\mathrm{a}}$ Ed., Tübingen: Mohr Siebeck, 2003.

RIED UNDURRAGA, José Miguel, "Fundamentos de la Prohibición del Uso de la Información Privilegiada en Chile: Una visión crítica", Revista Chilena de Derecho, Vol. 31, N³ (2004), pp. 439-463.

"El caso Consorcio 2 - Banco de Chile: Información Privilegiada y Potestad sancionadora de la Administración, en: Sentencias Destacadas 2005 una mirada desde la perspectiva de las políticas públicas", Revista del Instituto Libertad y Desarrollo, Santiago, 2005, pp. 31-44.

ROGALL, Klaus, "Gegenwartsprobleme des Umweltstrafrechts", en: VVAA, Festschrift der Rechtswissenschaftlichen Fakultät zur 600-Jahr-Feier der Universität zu Köln, Köln, 1988, pp. 505 y ss.

ROJAS, Luis Emilio, "Perjuicio Patrimonial e Imputación Objetiva", Revista de Derecho de la Pontificia Universidad Católica de Valparaíso: Vol. XXXVII, $2^{\circ}$ Semestre de 2011, pp. 417-420.

ROSAS, Juan Ignacio, "El Delito de Abuso de Información Privilegiada en el Mercado de Valores: Análisis crítico de la regulación contenida en la Ley $\mathrm{N}^{\circ} 18.045$ ", Revista Gaceta Jurídica, N² 299 (2005), pp. 7-24.

ROXIN, Claus, "Es la Protección de bienes jurídicos una finalidad del derecho penal?", en: HEFENDEHL, Roland (Ed.), Teoría del Bien Jurídico, Madrid: Ed. Marcial Pons, 2007, pp. 443 y ss.

SALAH ABUSLEME, María Agnes, Responsabilidad por uso de Información Privilegiada en el Mercado de Valores, Santiago: Lexis Nexis, 2004.

SCHÜNEMANN, Bernd, "Moderne Tendenzen in der Dogmatik der Fahrlässigkeit", JA, 1975, S. 787 y ss.

, "Das Rechtsgüterschutzprinzip als Fluchtpunkt der verfassungsrechtlichen Grenzen der Straftatbestände und ihrer Interpretation", en: HEFENDEHL, Roland (Ed.), Die Rechtsgutstheorie, Baden Baden: Nomos Verlagsgesellschaft, 2003, pp. 133 y ss.

SCHMIDT, Jürgen, Untersuchung zur Dogmatik und zum Abstraktionsgrad abstrakter Gefährdungsdelikte, Bd. 24. Marburg: N.G. Erwert Verlag Marburg, 1999.

SINA, Peter, Die Dogmengeschichte des strafrechtlichen Begriffs Rechtsgut, Basel (Suiza): Helbing \& Lichtenhahn, 1962.

STEINER, Manfred; BRUNS, Christoph, Wertpapiermanagement, Stuttgart, Alemania: Schäffer - Poeschel Verlag, 8. Ed., 2002.

STIPP, Anne Caroline, El Delito de Abuso de Información Privilegiada, Bogotá, Colombia: Editorial Leyer, 2009.

STRATENWERTH, Günter, "Zum Straftatbestand des Missbrauchs von Insiderinformationen", en: VV.AA., Festschrift für Frank Vischer, Editorial Schulthess Polygrafischer, Zurich, 1983, pp. 667-676.

THOMAS, Alexander, "Vertrauen im interkulturellen Kontext aus Sicht der Psychologie", en: THOMAS, A. (Ed.), Die Rolle von Vertrauen in Unternehmensplanung und Regionalentwicklung- ein interdisziplinärer Diskurs. München: Forost, Forschungsverbund Ost- und Südosteuropa, 2005. 
GARCÍA PALOMINOS, Gonzalo. "La idealización y la administrativización de la punibilidad del uso de Información Privilegiada. Un análisis de los discursos penales en la doctrina chilena".

VASQUEZ PALMA, María Fernanda, "Revisión del ámbito de aplicación subjetivo y objetivo de la noción de uso de información privilegiada en Chile: un examen de la normativa a la luz de las tendencias doctrinales y jurisprudenciales", Revista de Derecho Universidad Católica del Norte, Año 17, No 2 (2010), pp. 239-297.

WOHLERS, Wolfgang, Deliktstypen des Präventionsstrafrechts - zur Dogmatik „,moderner“ Gefährdungsdelikte, Basel: Duncker \& Humblot, 2000. "Kommentar § 264a y ss.", en: JOECKS, Wolfgang; MIEBACH, Klaus, Münchener Kommentar zum Strafgesetzbuch, Gesamtredaktion, München: Verlag C.H. Beck, 2006, número al márgen 24.

ZARHI, Oscar, "La teoría de los mercados eficientes como garantía de una correcta fiscalización del mercado de valores”, en: GONZÁLEZ, Marco (Ed.), Regulaciones en el mercado de valores, Cuadernos de Extensión Jurídica $N^{\circ}$ 19, Santiago: Universidad de los Andes, 2010, pp. 54 ss.

ZIOUVAS, Dimitris, Das neue Kapitalmarktstrafrecht Europäisierung und Legitimation, Köln: Editorial Carl Heymanns, 2005. 